Faculty of Science

Faculty Publications

This is a post-print version of the following article:

Phototautomerization in Pyrrolylphenylpyridine Terphenyl Systems

Nikola Basaric, Suma S. Thomas, Vesna Blazek Bregovic, Nikola Cindro \& Cornelia Bohne

March 2015

The final publication is available via American Chemical Society Publications at:

https://doi.org/10.1021/acs.joc.5b00275

Citation for this paper:

Basaric, N., Thomas, S. S., Bregovic, V. B., Cindro, N., \& Bohne, C. (2015). Phototautomerization in Pyrrolylphenylpyridine Terphenyl Systems. Journal of Organic Chemistry, 80(9), 4430-4442. https://doi.org/10.1021/acs.joc.5b00275. 


\section{Phototautomerization in pyrrolylphenylpyridine terphenyl systems}

Nikola Basarić, ${ }^{\dagger *}$ Suma S. Thomas, ${ }^{\ddagger}$ Vesna Blažek Bregović, ${ }^{\dagger}$ Nikola Cindro, ${ }^{\dagger}$ and Cornelia Bohne $* *$

$\dagger$ Department of Organic Chemistry and Biochemistry, Ruđer Bošković Institute, Bijenička cesta 54, 10000 Zagreb, Croatia. Fax: + 38514680 195; Tel: +385 14561141

\$ Department of Chemistry, University of Victoria, Box 3065 STN CSC, Victoria BC, V8W 3V6, Canada. Fax:+ 250721 7147; Tel:+ 2507217151

Corresponding authors' E-mail addresses: NB nbasaric@irb.hr; CB cornelia.bohne@gmail.com

\section{Graphical abstract}
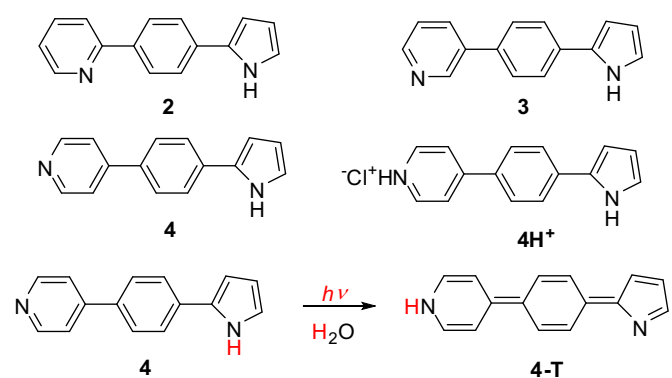

Abstract: [4-(2-Pyrrolyl)phenyl]pyridines 2-4 were synthesized and their photophysical properties and reactivity in phototautomerization reactions investigated by fluorescence spectroscopy and laser flash photolysis (LFP). The $\mathrm{p} K_{\mathrm{a}}$ for the protonation of the pyridine nitrogen in 2-4 was determined by UV-vis and fluorescence titration ( $\mathrm{p} K_{\mathrm{a}}=5.5$ for 4). On excitation in polar protic solvents $\mathbf{2 - 4}$ populate charge transfer (CT) states leading to an enhanced 
basicity of the pyridine $\left(\mathrm{p} K_{\mathrm{a}} * \approx 12\right)$ and enhanced acidity of pyrrole $\left(\mathrm{p} K_{\mathrm{a}} * \approx 8-9\right)$ enabling excited state proton transfer (ESPT). ESPT gives rise to phototautomers and significantly quenches the fluorescence of 2-4. Phototautomers 2-T and 4-T were detected by LFP with strong transient absorption maxima at $390 \mathrm{~nm}$. Phototautomers 2-T and 4-T decayed by competing uni- and bimolecular reactions. However, at $\mathrm{pH} 11$ the decay of 4-T followed exponential kinetics with a rate constant of $4.2 \times 10^{6} \mathrm{~s}^{-1}$. The pyridinium salt $\mathbf{4} \mathbf{H}^{+}$forms a stable complex with cucurbit[7]uril $(\mathrm{CB}[7])$ with $1: 1$ stoichiometry $\left(\beta_{11}=(1.0 \pm 0.2) \times 10^{5} \mathrm{M}^{-1},\left[\mathrm{Na}^{+}\right]=39 \mathrm{mM}\right)$. Complexation to $\mathrm{CB}[7]$ increased the $\mathrm{p} K_{\mathrm{a}}$ for $\mathbf{4} \mathbf{H}^{+}\left(\mathrm{p} K_{\mathrm{a}}=6.9\right)$ and changed its photochemical reactivity. Homolytic cleavage of the pyrrole $\mathrm{NH}$ leads to the formation of an N-radical because of the decreased acidity of the pyrrole in the inclusion complex.

Key words: excited state proton transfer (ESPT), pyridine, pyrrole, laser flash photolysis, inclusion complexes, cucurbit[7]uril

\section{Introduction}

Proton transfer is a fundamental reaction in chemistry and biology ${ }^{1}$ that has received much attention due to fundamental aspects, as well as numerous applications. ${ }^{2}$ Upon electronic excitation, some organic functional groups exhibit enhanced acidity or basicity. ${ }^{3,4}$ If these sites are in close proximity, excitation can lead to excited-state intramolecular proton transfer (ESIPT). ${ }^{5,6,7,8}$ However, if the basic and acidic sites are not at a short distance, proton transfer can be feasible either via double proton transfer or via a relay mechanism over bridges of protic molecules. ${ }^{9}$ The latter process is particularly interesting in biological systems and involves chains of polar amino acids and $\mathrm{H}_{2} \mathrm{O}$ molecules, ${ }^{10,11,12}$ or coupled electron transfer and proton 
transfer. ${ }^{13,14}$ Long-range proton transfer also takes place in respiratory complexes, ${ }^{15}$ whereas absorption of light in bacteriorhodopsin enables the function of a proton pump that moves protons through a membrane against a gradient. ${ }^{16,17}$ The mechanism of ESPT that involves solvent-relay shuffling of a proton has been documented for 7 -azaindoles ${ }^{18}$ and 7 hydroxyquinoline, ${ }^{19,20,21,22,23}$ and has been used for the probing of structural dynamics in proteins. ${ }^{24}$ Furthermore, proton transfer taking place via relay of $\mathrm{H}_{2} \mathrm{O}$-molecules has been used to study dynamics of membranes and micelles. ${ }^{25,26,27}$

ESIPT in the pyrrolylpyridine systems has been well documented. ${ }^{28}$ In these examples the pyrrole or indole $\mathrm{NH}$ is the acidic site, whereas the pyridine nitrogen is the basic site. $29,30,31,32,33$ For example, photoexcitation of pyrrolylpyridine 1 in nonpolar solvents leads to ESIPT and to the population of phototautomer 1-T (Eq. 1) which was detected by fluorescence spectroscopy. ${ }^{31}$ In the corresponding meta and para pyridine derivatives wherein the acidic and basic sites are distant, solvent-assisted double proton transfer occurs giving rise to phototautomers, or $\mathrm{H}$ bonding complexes with the solvent are formed, leading to a de-excitation via an internal conversion channel. ${ }^{34,35,36}$

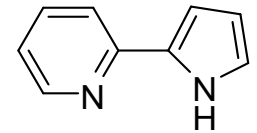

1

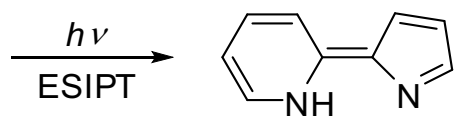

$1-\mathrm{T}$

Herein we report on the investigation of solvent-assisted phototautomerization (formal proton transfer) in a series of pyrrolylphenylpyridine terphenyl derivatives 2-4. The photophysical properties of molecules 2-4 were investigated by fluorescence spectroscopy, whereas formation of the phototautomers was probed by laser flash photolysis (LFP). Furthermore, the complexation of $\mathbf{4} \mathbf{H}^{+}$with cucurbit[7]uril (CB[7]) was investigated, because inclusion complexes 
with $\mathrm{CB}[\mathrm{n}] \mathrm{s}$ were shown to alter photochemical reactivity ${ }^{37}$ and these complexes have been the focus of intensive research, ${ }^{38}$ particularly owing to the potential applicability as drug delivery vehicles $^{39,40,41}$ or photoswitches. ${ }^{42,43}$ Herein we demonstrate that complexation of $\mathbf{4} \mathbf{H}^{+}$with $\mathrm{CB}[7]$ changes its photochemical reactivity and prevents phototautomerization.
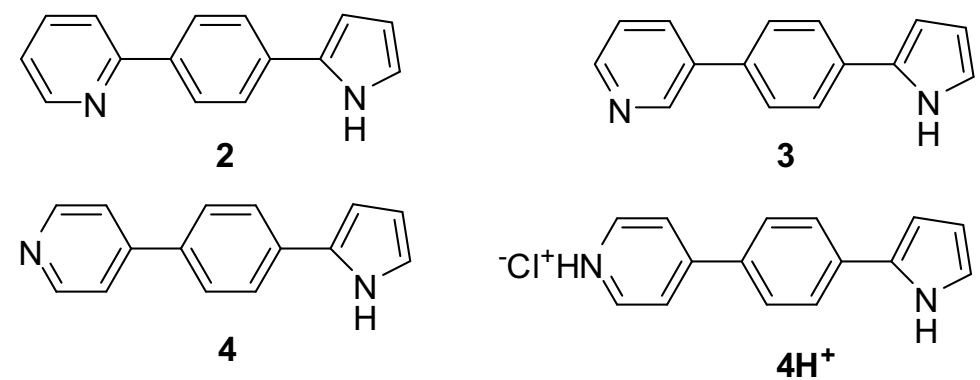

\section{Results}

\section{Synthesis}

Pyrrole derivatives 2-4 were prepared from the corresponding (4-bromophenyl)pyridines (Schemes 1-3). For the ortho derivative, 4-bromophenyl boronic acid (5) was prepared first, that in the Suzuki coupling with 2-bromopyridine afforded 2-(4-bromophenyl)pyridine $(6)^{44,45}$ in the yield of $29 \%$. The subsequent Suzuki reaction with the pyrrole boronic acid, ${ }^{46}$ according to the optimized conditions for the arylation with pyrrole $^{47}$ and the Boc-deprotection in basic conditions (Scheme 1) gave the target compound $2 .{ }^{48}$

Scheme 1. 


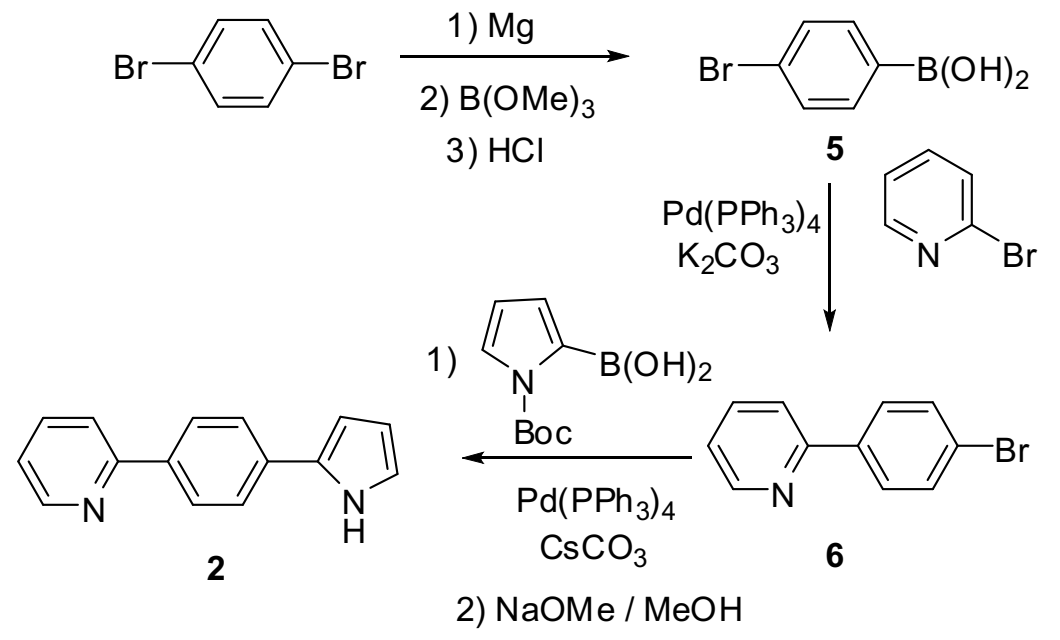

Synthesis of meta derivative $\mathbf{3}$ started from the commercially available 3-pyridine boronic acid that was arylated in a Suzuki coupling to afford bromide $7,{ }^{49,50}$ and subsequently in another Suzuki coupling with pyrrole boronic acid gave 3-Boc derivative. Boc-deprotection in basic conditions gave the target compound in the overall yield of $\approx 20 \%$ (Scheme 2 ).

Scheme 2.

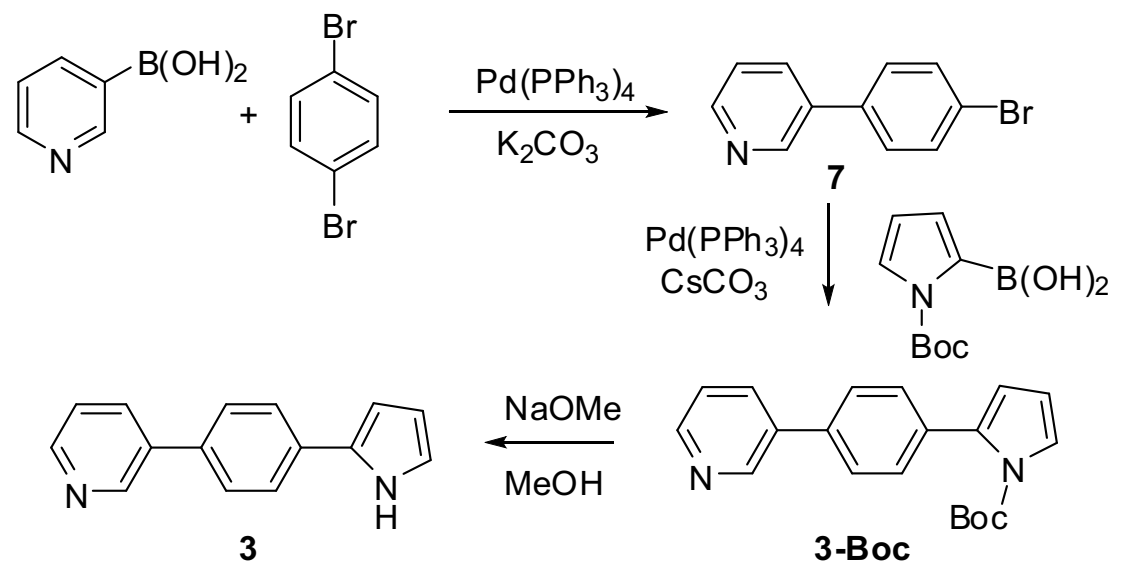


The synthetic strategy for para-derivative $\mathbf{4}$ was different than for $\mathbf{2}$ and $\mathbf{3}$ since bromide $\mathbf{8}$ was not prepared in a metal-catalyzed cross-coupling. Instead, according to a modification of the published procedure, ${ }^{51}$ pyridine was activated by transforming it to a triflate salt, which enabled nucleophilic addition of $p$-bromophenyllithium generated in situ. The reaction gave the 1,2(minor) and 1,4-adducts (major) which were isolated as a mixture and without characterization treated with a base to afford $\mathbf{8}^{48}$ as the major product, isolated in the overall yield of $25 \%$. Subsequent arylation with pyrrole boronic acid, as for the ortho and meta derivative, and Bocdeprotection gave the target compound (Scheme 3).

Scheme 3.

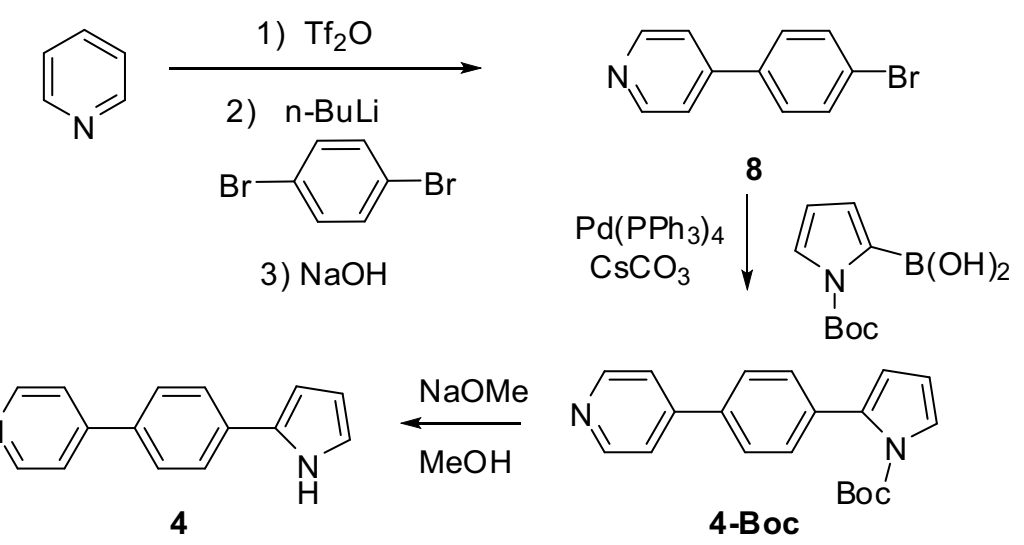

\section{Fluorescence measurements}

Absorption spectra of 2-4 taken in $\mathrm{CH}_{3} \mathrm{CN}$ (Fig. 1 top) exhibit an absorption band with a maximum at around $327 \mathrm{~nm}$ corresponding to the HOMO-LUMO transition and population of $\mathrm{S}_{1}$. The geometries of the two conformers of $\mathbf{4}$ and orbitals involved in the electronic transition are presented in the supporting information (Fig. S1 and S2, Tables S1, S3 and S4 in the SI). The 
excitation has a significant charge transfer (CT) character, leading to an electron density enhancement on the pyridine and a decrease on the pyrrole.

Fluorescence spectra of 2-4 were measured in cyclohexane, $\mathrm{CH}_{3} \mathrm{CN}$ and $\mathrm{CH}_{3} \mathrm{CN}-\mathrm{H}_{2} \mathrm{O}(1: 1$, Fig. 1 bottom and Fig. S5-S12 in the SI). In cyclohexane, the fluorescence spectra of $\mathbf{2 - 4}$ are structured with a vibronic progression of $1400 \mathrm{~cm}^{-1}$. The increase in solvent polarity shifts the maximum of the emission to longer wavelengths (Fig. 1 bottom, and Fig. S7, S9, S11 in the SI), and leads to a disruption of the vibronic structure. These findings suggest an increase of the dipole moment for the excited state, in agreement with the calculation for 4 (see Table S3 in the SI).
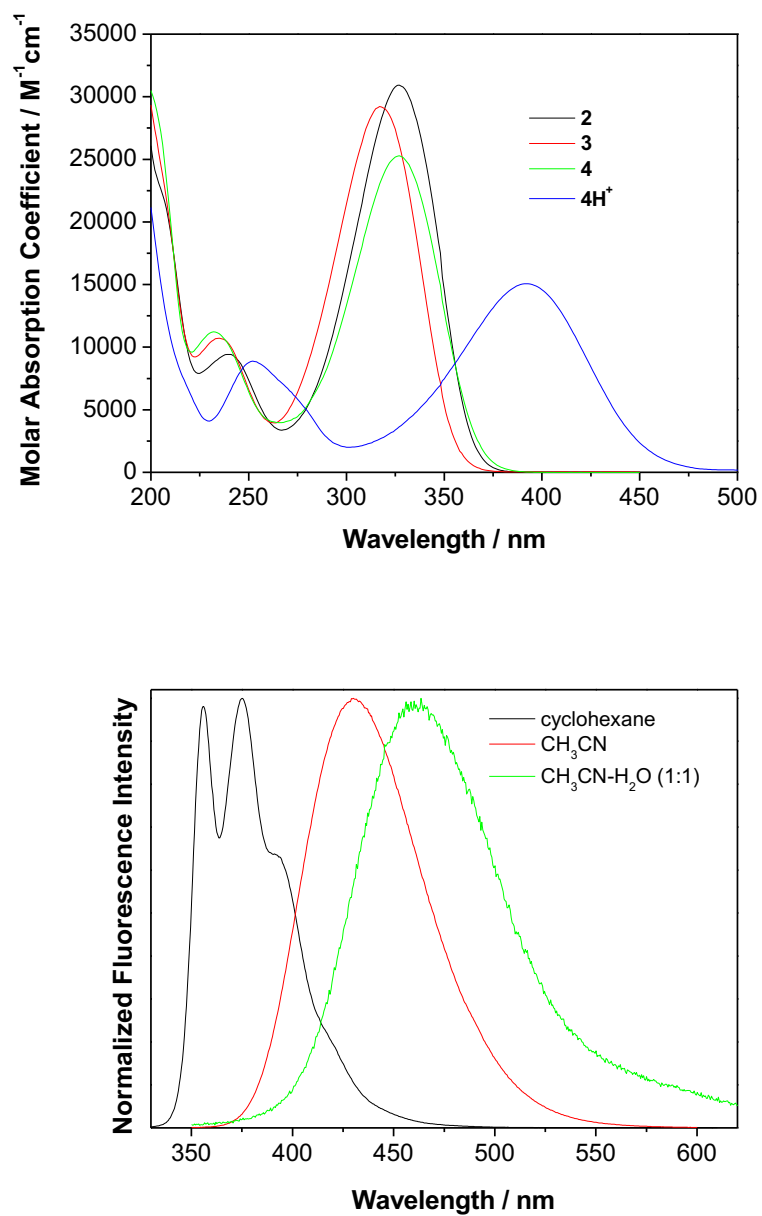
Fig 1. Absorption spectra of $\mathbf{2 - 4}$, and $\mathbf{4} \mathbf{H}^{+}$in $\mathrm{CH}_{3} \mathrm{CN}$ (top), and normalized fluorescence spectra of 4 in different solvents (bottom).

Quantum yields of fluorescence for 2-4 were measured by use of quinine sulfate / $0.05 \mathrm{M} \mathrm{H}_{2} \mathrm{SO}_{4}$ as a reference (see equation S1 in the SI), whereas lifetimes were measured by time-correlated single photon counting (SPC). Similar quantum yields were measured for $\mathbf{2 - 4}$ in cyclohexane and $\mathrm{CH}_{3} \mathrm{CN}$ (Table 1). The decays from $\mathrm{S}_{1}$ for $\mathbf{2 - 4}$ were faster in cyclohexane than in $\mathrm{CH}_{3} \mathrm{CN}$, and in cyclohexane the kinetics were fit to a sum of two exponentials, while the kinetics was fit to a monoexponential function in $\mathrm{CH}_{3} \mathrm{CN}$ (Table 1). Although straightforward assignment of decay components in cyclohexane is not possible at this point, the observation could be interpreted as due to locally excited (LE) and charge transfer (CT) states, or aggregation of molecules in that solvent. However, fine vibronic structure observed in the steady state spectra in cyclohexane does not suggest aggregation. Nevertheless, in $\mathrm{CH}_{3} \mathrm{CN}$ only one $\mathrm{S}_{1}$ state is populated with a significant $\mathrm{CT}$ character wherein the pyrrole moiety becomes relatively positively charged (and therefore, more acidic than in $\mathrm{S}_{0}$ ) and the pyridine relatively negatively charged (more basic than in $\left.\mathrm{S}_{0}\right)$.

Table 1. Photophysical properties of $\mathbf{2 - 4}$ and $\mathbf{4} \mathbf{H}^{+}$

\begin{tabular}{lllllll}
\hline & $\Phi^{\mathrm{a}}$ & $\tau^{\mathrm{b}}$ & $\Phi^{\mathrm{a}}$ & $\tau^{\mathrm{b}}$ & $\Phi^{\mathrm{a}}$ & $\tau^{\mathrm{b}}$ \\
& $($ cyclo. $)$ & $($ cyclo. $) / \mathrm{ns}$ & $\left(\mathrm{CH}_{3} \mathrm{CN}\right)$ & $\left(\mathrm{CH}_{3} \mathrm{CN}\right) / \mathrm{ns}$ & $\left(\mathrm{CH}_{3} \mathrm{CN}-\mathrm{H}_{2} \mathrm{O}\right)$ & $\left(\mathrm{CH}_{3} \mathrm{CN}-\mathrm{H}_{2} \mathrm{O}\right) / \mathrm{ns}$ \\
\hline $\mathbf{2}$ & $0.90 \pm 0.03$ & $(60-120) \times 10^{-3}$ & $0.95 \pm 0.05$ & $2.14 \pm 0.01$ & $0.046 \pm 0.003$ & $(90-120) \times 10^{-3}$ \\
& & & & & $0.40 \pm 0.05$ \\
& & & & & & \\
$\mathbf{3}$ & $0.90 \pm 0.02$ & $(70-100) \times 10^{-3}$ & $0.83 \pm 0.03$ & $2.28 \pm 0.01$ & &
\end{tabular}




\begin{tabular}{|c|c|c|c|c|c|c|}
\hline \multirow[t]{2}{*}{4} & $0.95 \pm 0.02$ & $(60-100) \times 10^{-3}$ & $0.91 \pm 0.03$ & $2.29 \pm 0.01$ & $0.049 \pm 0.003$ & $(90-150) \times 10^{-3}$ \\
\hline & & $1.41 \pm 0.01$ & & & & $0.3 \pm 0.1$ \\
\hline \multirow[t]{2}{*}{$4 \mathbf{H}^{+}$} & - & - & $0.012 \pm 0.002$ & $0.11 \pm 0.01$ & - & - \\
\hline & & & c & $0.68 \pm 0.02$ & & \\
\hline
\end{tabular}

a Fluorescence quantum yields measured by use of quinine sulfate in $0.05 \mathrm{M} \mathrm{H}_{2} \mathrm{SO}_{4}$ as a reference $\left(\Phi_{\mathrm{f}}=0.53\right){ }^{52}$ Errors correspond to averaged data measured at three different wavelengths.

b Measured by SPC. Errors correspond to those obtained by global fitting of three decays at different emission wavelengths. The pre-exponential factors for the fastest lifetime of the nonexponential decays were: 0.03-0.05 in cyclohexane, 0.6-0.95 in $\mathrm{CH}_{3} \mathrm{CN}-\mathrm{H}_{2} \mathrm{O}$ with a significant dependence on the emission wavelengths, and 0.4-0.5 for $\mathbf{4} \mathbf{H}^{+}$in $\mathrm{CH}_{3} \mathrm{CN}$.

c Estimated fluorescence quantum yield measured for the emission band at $570 \mathrm{~nm}$ by use of acridine yellow in $\mathrm{CH}_{3} \mathrm{OH}$ as a reference $\left(\Phi_{\mathrm{f}}=0.57\right) .{ }^{53}$ Errors correspond to averaged data measured at three different wavelengths.

Protonation of the pyridine nitrogen in $\mathbf{4} \mathbf{H}^{+}$significantly shifts the position of the absorption maximum bathochromically to $393 \mathrm{~nm}$ (Fig. 1, top) owing to a larger stabilization of $\mathrm{S}_{1}$ than $\mathrm{S}_{0}$ by protonation of 4 . However, dilution of the solution (from $5 \times 10^{-5} \mathrm{M}$ to $5 \times 10^{-6} \mathrm{M}$ ) changes the appearance of the spectrum with the shift of the maximum to $327 \mathrm{~nm}$ (Fig. S13 in the SI). Although these spectral changes could be related to deaggregation of the molecules by dilution, the spectral changes are consistent with the deprotonation of $\mathbf{4} \mathbf{H}^{+}$because the changes parallel those observed in the $\mathrm{pH}$ titration. Therefore, $\mathbf{4} \mathbf{H}^{+}$in $\mathrm{CH}_{3} \mathrm{CN}$ behaves as a weak acid suggesting that both $\mathbf{4}$ and $\mathbf{4} \mathbf{H}^{+}$are present in solution. 
Fluorescence spectra of $\mathbf{4} \mathbf{H}^{+}$in $\mathrm{CH}_{3} \mathrm{CN}$ are also strongly dependent on concentration (Fig. S14 in the SI) with two emission maxima at 430 and $570 \mathrm{~nm}$, corresponding to $\mathbf{4}$ and $\mathbf{4} \mathbf{H}^{+}$, respectively. Moreover, the fluorescence decay of $\mathbf{4} \mathbf{H}^{+}$in $\mathrm{CH}_{3} \mathrm{CN}$ is bi-exponential, due the presence of $\mathbf{4}$ and $4 \mathbf{H}^{+}$. The fluorescence quantum yield of $\mathbf{4} \mathbf{H}^{+}$in $\mathrm{CH}_{3} \mathrm{CN}\left(c=5 \times 10^{-6} \mathrm{M}\right)$ measured for the emission between 430 and $750 \mathrm{~nm}$ was estimated by exciting the sample at ca. $410 \mathrm{~nm}$ where only $4 \mathbf{H}^{+}$absorbs, giving a value about 75 times lower than for 4 . Increase of temperature also led to the deprotonation of $\mathbf{4 H}^{+}$, as indicated by the change of the relative intensities of the bands at $430 \mathrm{~nm}$ and $570 \mathrm{~nm}$ (Fig. S15 in the SI). These fluorescence results are consistent with the changes observed in the absorption spectra when the concentration of $\mathbf{4} \mathbf{H}^{+}$was altered. Addition of a protic solvent $\left(\mathrm{H}_{2} \mathrm{O}\right)$ to the $\mathrm{CH}_{3} \mathrm{CN}$ solution strongly quenches the fluorescence of 2-4. This finding indicates that a protic solvent opens an efficient deactivation channel from $S_{1}$. As discussed above, 2-4 populate CT states in a polar solvent wherein the pyridine nitrogen becomes more basic and the pyrrole more acidic. Therefore, quenching of fluorescence in the presence of protic solvent can be rationalized by ESPT leading to the protonation of the pyridine nitrogen and/or deprotonation of the pyrrole NH (Scheme 4). Furthermore, a new shoulder appears $(\lambda>550 \mathrm{~nm})$ in the fluorescence spectrum of 4 taken in $\mathrm{CH}_{3} \mathrm{CN}-\mathrm{H}_{2} \mathrm{O}$ (Fig. S5, S6, S11 and S12 in the SI) that is associated with the fluorescence of $\mathbf{4} \mathbf{H}^{+}$formed by ESPT (see below). Decays of fluorescence of 2-4 in $\mathrm{CH}_{3} \mathrm{CN}-\mathrm{H}_{2} \mathrm{O}$ were multi-exponential, but due to the presence of a very fast component, analysis of the decay components was not possible with the SPC equipment used. 
Scheme 4. Phototautomerization of $\mathbf{4}$ and formation of its radical in aqueous solution depending on $\mathrm{pH}$.
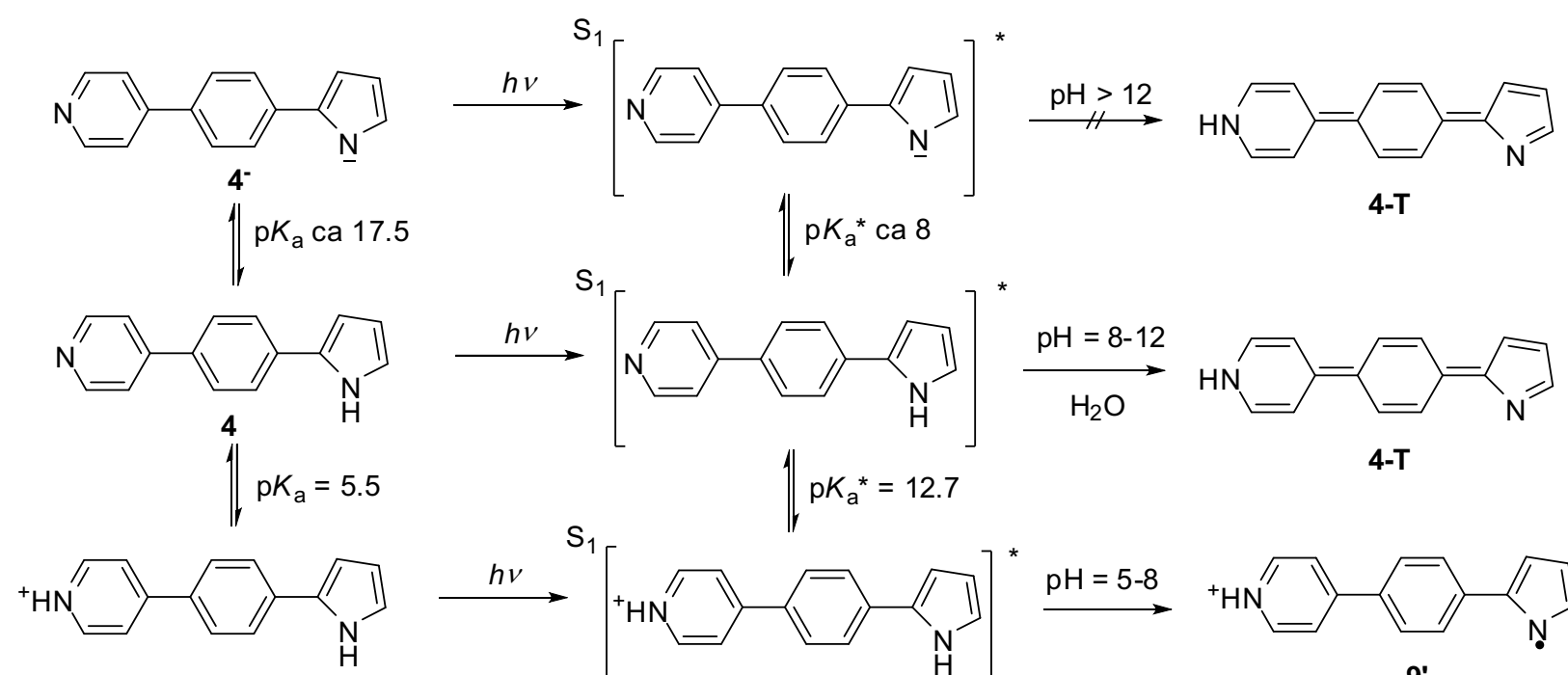

$4 \mathrm{H}^{+}$
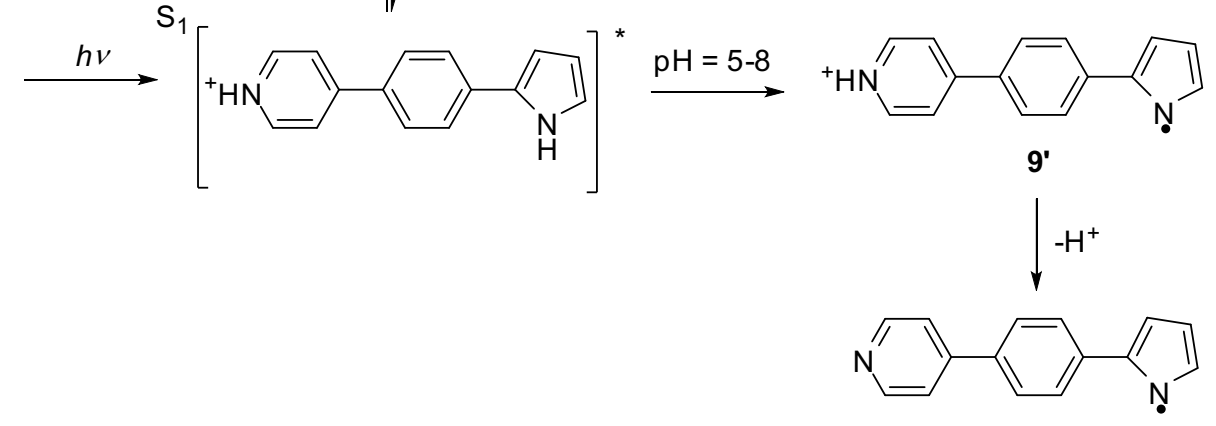

10

Acid-base properties were investigated for $\mathbf{2 - 4}$ by UV-vis and fluorescence titrations. For para derivative 4, the $\mathrm{pH}$ titrations were performed in $\mathrm{H}_{2} \mathrm{O}$ in the absence of a buffer, and in the presence of phosphate or citrate buffers at two different concentrations of 4 . The variation of $\mathrm{pH}$ in the range 3-7 induced UV-vis and fluorescence spectral changes (Fig. 2). These spectra were processed by multivariate nonlinear regression analysis using the SPECFIT software ${ }^{54,55,56}$ to reveal the $\mathrm{p} K_{\mathrm{a}}$ of $5.5 \pm 0.1$ determined using different methods (Fig. S26-S37 and Table S9 in the SI). This value matches with the $\mathrm{p} K_{\mathrm{a}}$ for the protonation of the pyridine nitrogen $\left(\mathrm{p} K_{\mathrm{a}}=5.2\right) .{ }^{57}$ Similar spectral changes were observed in the UV-vis pH titrations of 2 and $\mathbf{3}$ (Figs S16, S17, 
S22 and S23) which were processed by SPECFIT software to reveal the $\mathrm{p} K_{\mathrm{a}}$ values of $\approx 4.8$ (see Tables S7 and S8 in the SI).

The $\mathrm{p} K_{\mathrm{a}}{ }^{*}$ value for the protonation of the pyridine nitrogen in 4 in $\mathrm{S}_{1}$ was estimated from the fluorescence titration by use of the Förster cycle. ${ }^{3}$ Nonlinear regression analysis of the fluorescence titration data revealed the position of the emission maxima in aqueous solution for 4 and $\mathbf{4} \mathbf{H}^{+}$at 484 and $580 \mathrm{~nm}$, respectively (Table S9 in the SI). These values correspond to the increase of basicity of the pyridine nitrogen on excitation to $\mathrm{S}_{1}$ of $\Delta \mathrm{p} K=7.2 \pm 0.2$; that is, the estimated value of $\mathrm{p} K_{\mathrm{a}}{ }^{*}$ is $12.7 \pm 0.2$. For $\mathbf{2}$ and $\mathbf{3}$ Förster cycle analysis could not be applied to determine $\mathrm{p} K_{\mathrm{a}}{ }^{*}$ for the protonation of pyridine since the corresponding protonated form $2 \mathbf{H}^{+}$is not fluorescent, and due to generally very weak fluorescence of both $\mathbf{3}$ and $\mathbf{3} \mathbf{H}^{+}$(see Figs S18$\mathrm{S} 21, \mathrm{~S} 24$ and S25 in the SI). In contrast to pyridine, pyrrole behaves as a weak acid. The reported $\mathrm{p} K_{\mathrm{a}}$ value for deprotonation of pyrrole is $17.5 .^{57}$ Therefore, we could not determine the $\mathrm{p} K_{\mathrm{a}}$ for the deprotonation of pyrrole for compound $\mathbf{4}$ in the aqueous solution.

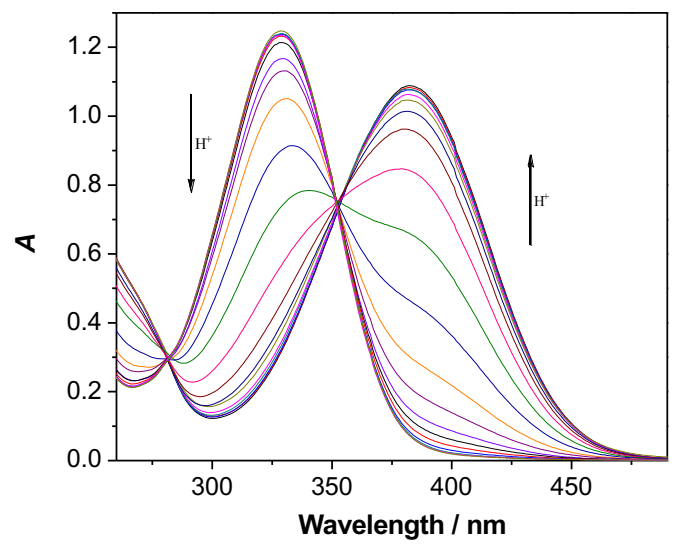




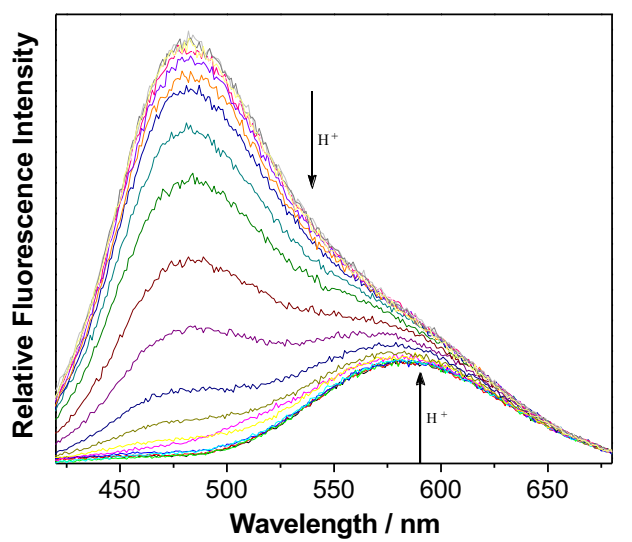

Fig. 2. UV-vis (top, [4] $=5.3 \times 10^{-5} \mathrm{M}$ ) and fluorescence spectra (bottom, $\lambda_{\mathrm{ex}}=350 \mathrm{~nm}$, [4] $=5.3 \times$ $10^{-6} \mathrm{M}$ ) at different $\mathrm{pH}$ values (from 3.0 to 7.5$)$ in the presence of citrate buffer $(0.05 \mathrm{M})$.

\section{Inclusion complex with cucurbit[7]uril (CB[7])}

Positively charged $\mathbf{4} \mathbf{H}^{+}$is a good candidate to form a host-guest complex with $\mathrm{CB}[7]$. This macrocyclic host is known to bind well guests with positive charges and hydrophobic moieties, ${ }^{42}$ where the hydrophobic moiety fits within the cavity of the $\mathrm{CB}[\mathrm{n}]$ and the positive charge is stabilized by interaction with the carbonyl groups. The association equilibrium constant was determined by UV-vis titration. To assure that the solution contained only $\mathbf{4} \mathbf{H}^{+}$, the titration was performed at $\mathrm{pH} 3.5$ in the presence of citrate buffer. Addition of $\mathrm{CB}$ [7] induced a hypochromic and very weak bathochromic shift indicative of complex formation (Fig. 3). An overall binding model with the formation of a 1:1 complex between $\mathbf{4} \mathbf{H}^{+}$and $\mathrm{CB}[7]$ was employed (see the SI, page S29) where the binding of sodium cations $(39 \mathrm{mM})$ to $\mathrm{CB}$ [7] was not accounted for in separate equilibria. The overall binding constant ${ }^{58} \beta_{11}$ of $(1.0 \pm 0.2) \times 10^{5} \mathrm{M}^{-1}$ was determined from two independent experiments for the absorption change at 360, 380 and $390 \mathrm{~nm}$ (Fig. S38S39 and Table S11 in the SI). 


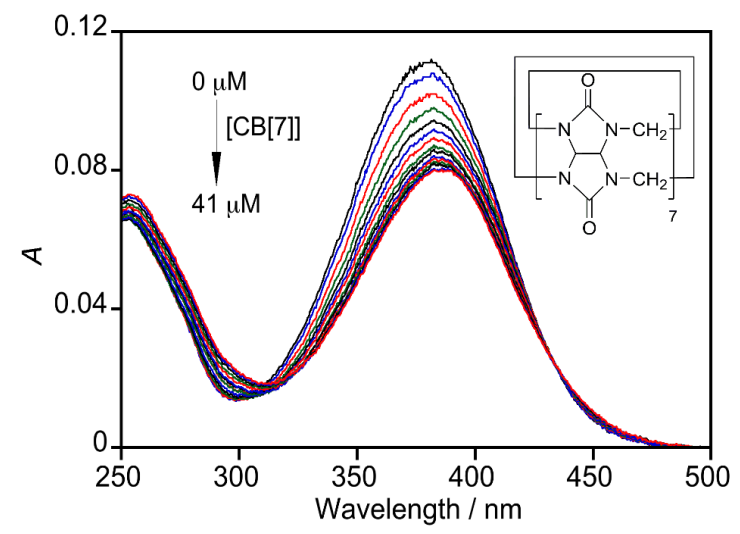

Fig 3. Absorption spectra for $\mathbf{4} \mathbf{H}^{+}(5 \mu \mathrm{M})$ in citrate buffer $\left(47 \mathrm{mM}, \mathrm{pH}=3.5,\left[\mathrm{Na}^{+}\right] 39 \mathrm{mM}\right)$ in the absence and presence of different concentrations of $\mathrm{CB}[7]$.

Complexation with $\mathrm{CB}[\mathrm{n}]$ changes the $\mathrm{p} K_{\mathrm{a}}$ of bound guest molecules, ${ }^{59,60}$ and therefore influences ESIPT reactivity of complexed guests. ${ }^{61}$ This variation of $\mathrm{p} K_{\mathrm{a}}$ upon complexation was used for logic gates ${ }^{62}$ or drug delivery systems. ${ }^{63,64,65}$ Therefore, we investigated the use of CB[n] to modulate the $\mathrm{p} K_{\mathrm{a}}$ of 4 by performing titrations with $\mathrm{CB}[7]$ in non-buffered solution wherein the formation of the inclusion complex is anticipated to lead to the pyridine protonation. In the titration experiment, an aqueous solution of $\mathrm{CB}$ [7] containing $100 \mathrm{mM} \mathrm{NaCl}$ was added to solutions of 4 in $\mathrm{CH}_{3} \mathrm{CN}-\mathrm{H}_{2} \mathrm{O}(1: 9$ or 1:99, both containing $100 \mathrm{mM} \mathrm{NaCl})$. The band at $330 \mathrm{~nm}$ disappeared with concomitant formation of a new band at $390 \mathrm{~nm}$ (Fig. 4 and Fig. S40 in the SI). The titration data resemble the ones seen in the $\mathrm{pH}$ titration (Fig. 2 top), where the absorption with maximum at $390 \mathrm{~nm}$ corresponds to $\mathbf{4} \mathbf{H}^{+}$. This finding indicates that $\mathrm{CB}$ [7] enhances the basicity of $\mathbf{4}$, leading to a stabilization of $\mathbf{4} \mathbf{H}^{+}$in the inclusion complex.

To determine the $\mathrm{p} K_{\mathrm{a}}$ of $\mathbf{4} \mathbf{H}^{+}$in the $\mathrm{CB}[7]$ complex we performed a $\mathrm{pH}$ titration of $\mathbf{4}$ in the presence of a large excess of $\mathrm{CB}[7](0.5 \mathrm{mM})$ to ensure that all 4 is bound to the complex, since it is known that the neutral form of guests have a lower stability constants than the cationic forms. ${ }^{38,42,43}$ The resulting UV-vis spectra (Fig. S41 in the SI) were processed by multivariate 
nonlinear regression analysis using the SPECFIT program ${ }^{54,55,56}$ to reveal the $K_{\mathrm{a}}$ value of $6.97 \pm$ 0.05. The higher $\mathrm{p} K_{\mathrm{a}}$ value $\left(\Delta \mathrm{p} K_{\mathrm{a}} \approx 1.5\right)$ is in accordance with the precedent literature. ${ }^{59,60}$

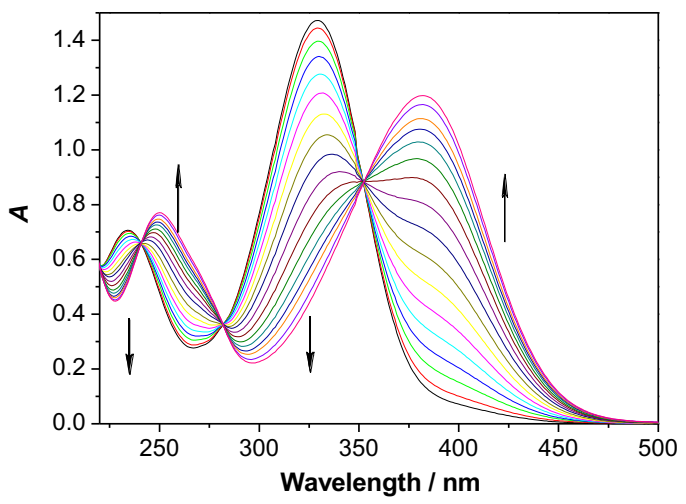

Fig. 4. Absorption spectra for the titration of $4\left(5 \times 10^{-5} \mathrm{M}\right.$ in $\left.\mathrm{CH}_{3} \mathrm{CN}-\mathrm{H}_{2} \mathrm{O} 1: 10,100 \mathrm{mM} \mathrm{NaCl}\right)$ with $\mathrm{CB}[7]\left(1 \mathrm{mM}\right.$ in $\left.\mathrm{H}_{2} \mathrm{O}, 100 \mathrm{mM} \mathrm{NaCl}, \mathrm{CB}[7]=0-6 \times 10^{-5} \mathrm{M}\right)$ in the absence of buffer. The curves were corrected for dilution.

\section{Laser Flash Photolysis (LFP)}

LFP measurements for solutions in $\mathrm{CH}_{3} \mathrm{CN}$ and $\mathrm{CH}_{3} \mathrm{CN}-\mathrm{H}_{2} \mathrm{O}$ were performed for isomers 2-4, as well as for the salt of $\mathbf{4} \mathbf{H}^{+}$to probe for the formation of phototautomers by ESPT. No phototautomers are expected to be formed in $\mathrm{CH}_{3} \mathrm{CN}$. Transient absorption spectra for isomers 24 in $\mathrm{CH}_{3} \mathrm{CN}$ showed an absorption band with a maximum at $410 \mathrm{~nm}$, and a weaker band at 680 nm (Fig. 5). Addition of $\mathrm{H}_{2} \mathrm{O}$ to the $\mathrm{CH}_{3} \mathrm{CN}$ solution significantly changed the appearance of the transient absorption (Fig. 5 and Fig S42 in the SI). The results in $\mathrm{CH}_{3} \mathrm{CN}$ (Fig. 5, black lines) will be described first where for 2, 3 and $\mathbf{4}$ the same transients were observed (Fig. S43-S49 in the SI). These were assigned to radical-cations (9), which absorb at $680 \mathrm{~nm}$, and pyrrolyl Ncentered (10) radicals, which absorb at $410 \mathrm{~nm}$ (Scheme 5) according to the comparison with 
published transient spectra for phenylpyrroles ${ }^{66}$ and indoles. ${ }^{67,68}$ The decay of the transient absorption measured in $\mathrm{CH}_{3} \mathrm{CN}$ was fit to a sum of two exponentials $\left(k \approx 9 \times 10^{5} \mathrm{~s}^{-1}\right.$ and $1 \times 10^{5} \mathrm{~s}^{-1}$ for $2,1 \times 10^{6} \mathrm{~s}^{-1}$ and $1 \times 10^{5} \mathrm{~s}^{-1}$ for 3 , and $3 \times 10^{5} \mathrm{~s}^{-1}$ and $\approx 10^{4} \mathrm{~s}^{-1}$ for 4 ). The lifetimes were not affected by $\mathrm{O}_{2}$, in agreement with a previous report that $\mathrm{O}_{2}$ does not quench $\mathrm{N}$-centered radicals ${ }^{69}$ and radical-cations. ${ }^{66,67,68,69}$ Short-lived 9 absorbing in the visible part of the spectrum, and long-lived 10 absorbing at shorter wavelengths $(380-420 \mathrm{~nm})$, are probably formed in parallel processes. However, the observation of a growth kinetics with small amplitude in the transient absorption at $\approx 420 \mathrm{~nm}$ (Fig. S48 in the SI) suggested that sequential formation of 9 and decay of this transient leading to the longer lived $\mathbf{1 0}$ may also take place. Since the absorption of solvated electron was not detected, an electron acceptor in the formation of 9 could have been $\mathrm{H}^{\cdot}$ radicals which are produced in the parallel process, traces of $\mathrm{O}_{2}$ or $\mathrm{H}_{2} \mathrm{O}$ molecules, or 2-4 in $\mathrm{S}_{0}$ (less likely since radical-anions of $\mathbf{2 - 4}$ were not detected). Furthermore, in the homolytic cleavage of the pyrrole $\mathrm{N}-\mathrm{H}$ bond and formation of $\mathbf{1 0}$, $\mathrm{H}$-acceptors could have been 2-4 in $\mathrm{S}_{0}$, $\mathrm{CH}_{3} \mathrm{CN}$ or $\mathrm{O}_{2}$-molecules.

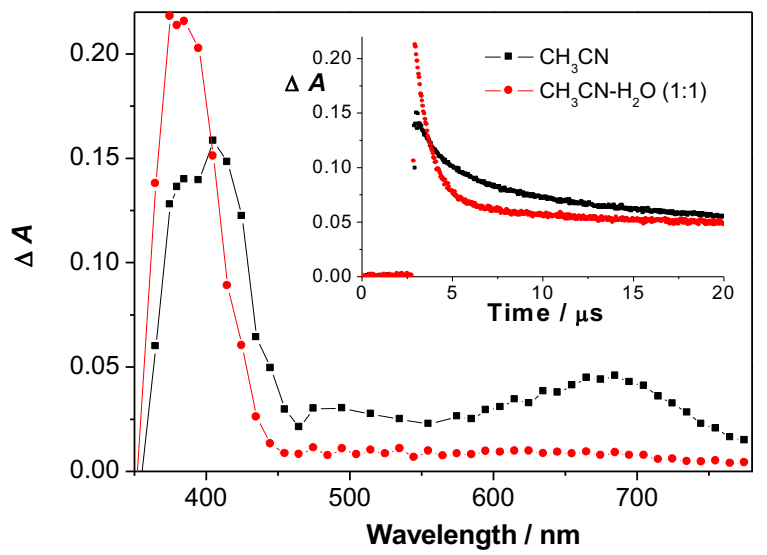




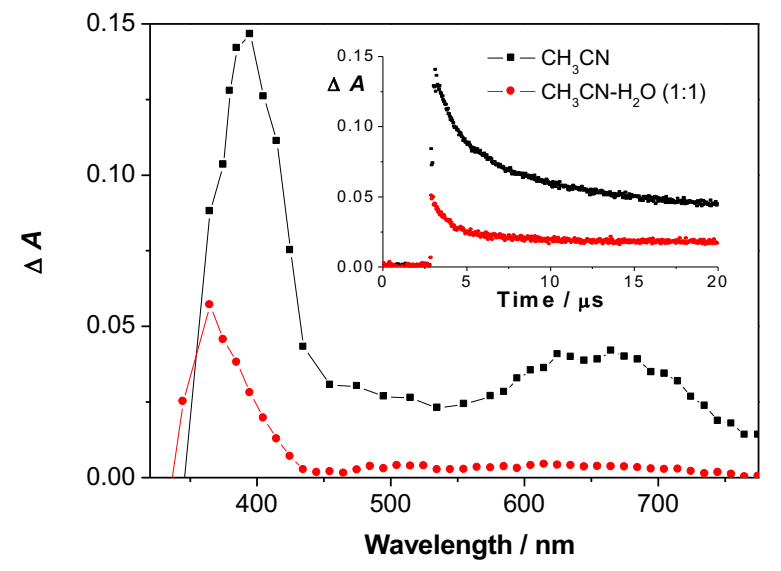

Fig. 5. Transient absorption spectra in $\mathrm{O}_{2}$ purged and optically matched $\left(A_{355} \approx 0.35\right)$ solutions for 2 (top) in $\mathrm{CH}_{3} \mathrm{CN}$ (delay $=500 \mathrm{~ns}$ ) and in $\mathrm{CH}_{3} \mathrm{CN}-\mathrm{H}_{2} \mathrm{O}$ (delay $=200 \mathrm{~ns}$ ); the inset shows the decays at $380 \mathrm{~nm})$. Transient absorption spectra in $\mathrm{O}_{2}$ purged and optically matched $\left(A_{355} \approx 0.32\right)$ solutions for 3 (bottom) in $\mathrm{CH}_{3} \mathrm{CN}$ (delay $=600 \mathrm{~ns}$ ) and $\mathrm{CH}_{3} \mathrm{CN}-\mathrm{H}_{2} \mathrm{O}$ (delay $=200 \mathrm{~ns}$ ); the inset shows the decays at $380 \mathrm{~nm}$.

Scheme 5. Photochemistry of 2-4 in aprotic solvent.

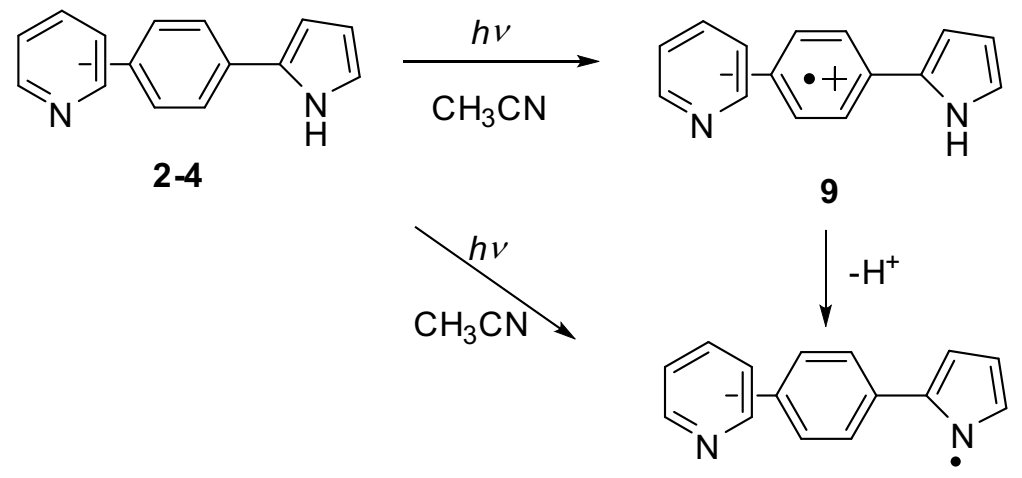

10

In $\mathrm{CH}_{3} \mathrm{CN}-\mathrm{H}_{2} \mathrm{O}$ solution for $\mathbf{2 - 4}$ the transient absorption band in the visible region was not detected (Fig. 5, Fig. S43-S47 and S49 in the SI), in accordance with the assignment of the 
transient observed in $\mathrm{CH}_{3} \mathrm{CN}$ to radical-cations, which in aqueous solution rapidly decay by proton transfer giving pyrrolyl radicals. Therefore, transients $\mathbf{9}$ are not observed when water is present but the absorption for transient $\mathbf{1 0}$ is present (vide infra for discussion on lifetimes). In the case of derivatives $\mathbf{2}$ and $\mathbf{4}$, but not $\mathbf{3}$, a new transient with absorption between 380 and 420 nm (Fig. 5, Fig. S42-S47 and S49 in the SI) was observed that is assigned to phototautomers 2-T (vide infra, scheme 7) and 4-T (Scheme 4) formed by ESPT. These species gave rise to a higher intensity of the transient absorbance at $380-420 \mathrm{~nm}$, compared to the spectra in $\mathrm{CH}_{3} \mathrm{CN}$ solutions when the absorbance values at the excitation wavelengths were matched (Fig. 5 top). In the case of $\mathbf{3}$, analysis of the kinetics (vide infra) showed that 3-T was not observed on the nanosecond time scale (Fig. S42, S45 and S46 in the SI). Therefore, the spectrum in $\mathrm{CH}_{3} \mathrm{CN}-\mathrm{H}_{2} \mathrm{O}$ (Fig. 5 bottom) corresponds only to intermediate $\mathbf{1 0}$.

The relative contribution of the species in the photochemistry of 2-4 (Scheme 4) is expected to be $\mathrm{pH}$ dependent for reactions in $\mathrm{CH}_{3} \mathrm{CN}-\mathrm{H}_{2} \mathrm{O}$ because the formation of phototautomers is $\mathrm{pH}$ dependent. At pH 11 (Fig. 6), the decay of the transient absorption was fit to a single-exponential function $\left(4.1 \times 10^{6} \mathrm{~s}^{-1}, \tau=240 \mathrm{~ns}\right)$ and was assigned to phototautomer 4-T that at this $\mathrm{pH}$ decays through a unimolecular process. A small off-set was observed at longer times which suggests that a long-lived transient was present. This transient was more prominent at lower $\mathrm{pHs}$ and corresponds to $\mathbf{1 0}$ (vide infra).

Decrease of the $\mathrm{pH}$ from 11 to $9-10$ led to slower kinetics and the decay could not be fit to a mono-exponential function. As will be shown below the kinetics correspond to a combination of bimolecular and unimolecular processes, where the bimolecular process is assigned to the reaction between two molecules of 4-T which competes with the unimolecular decay of 4-T. The bimolecular component only becomes apparent when the unimolecular decay of 4-T becomes 
slower at these lower $\mathrm{pH}$ values. The contribution of the bimolecular process was minimized by decreasing the energy of the laser pulse and the decay was fit by starting the fits at successively longer delay times after the laser pulse until the kinetics fit to a monoexponential function (eq. S3-S4 and Fig. S50 in the SI). The lifetime for the unimolecular decays of 4-T were $\approx 2 \mu$ s at $\mathrm{pH}$ 10, and $4 \mu$ s at $\mathrm{pH} 9$. A lengthening of the lifetime of 4-T is expected since 4-T undergoes base catalysis to recover 4. In addition to the decay of 4-T, another transient was observed that decayed over a much longer time window. This longer decay was fit to a monoexponential function and had a lifetime of $120 \mu \mathrm{s}\left(k=8.3 \times 10^{3} \mathrm{~s}^{-1}\right)$. This transient is assigned to $\mathbf{1 0}$ based on precedent in the literature. ${ }^{66,67,68,69}$

On decrease of the $\mathrm{pH}$ below 8-9, the characteristic strong signal assigned to 4-T disappeared. Thus, in neutral and acidic solution only the longer-lived transient species was detected assigned to radical 10, decaying through a unimolecular process $\left(k=8.3 \times 10^{3} \mathrm{~s}^{-1}, \tau=120 \mu \mathrm{s}\right)$. However, between $\mathrm{pH}$ values of 3 and 8 a new transient is observed (Fig. S51 in the SI). The lifetime for this transient was estimated to be shorter than $100 \mathrm{~ns}$, where this decay occurs over a short time window and levels off before the long-lived decay occurs. Since the short-lived transient was not detected in the visible part of the spectrum (at $680 \mathrm{~nm}$ ), it cannot correspond to radical-cation $\mathbf{9}^{\prime}$. According to the observation of the transient only at $\mathrm{pH} 3-8$, its short lifetime and the absorption at $390 \mathrm{~nm}$, it may be related to the equilibrium between $\mathbf{4}$ and $\mathbf{4} \mathbf{H}^{+}$in the ground state (Scheme 4). Upon excitation, singlet excited state 4 is protonated leading to $4 \mathbf{H}^{+}$because of the higher basicity in $\mathrm{S}_{1}$. Therefore this transient, was tentatively assigned to an excess of $\mathbf{4} \mathbf{H}^{+}$in $\mathrm{S}_{0}$ which then decays to re-establish the ground-state equilibrium between $\mathbf{4}$ and $\mathbf{4} \mathbf{H}^{+}$. 

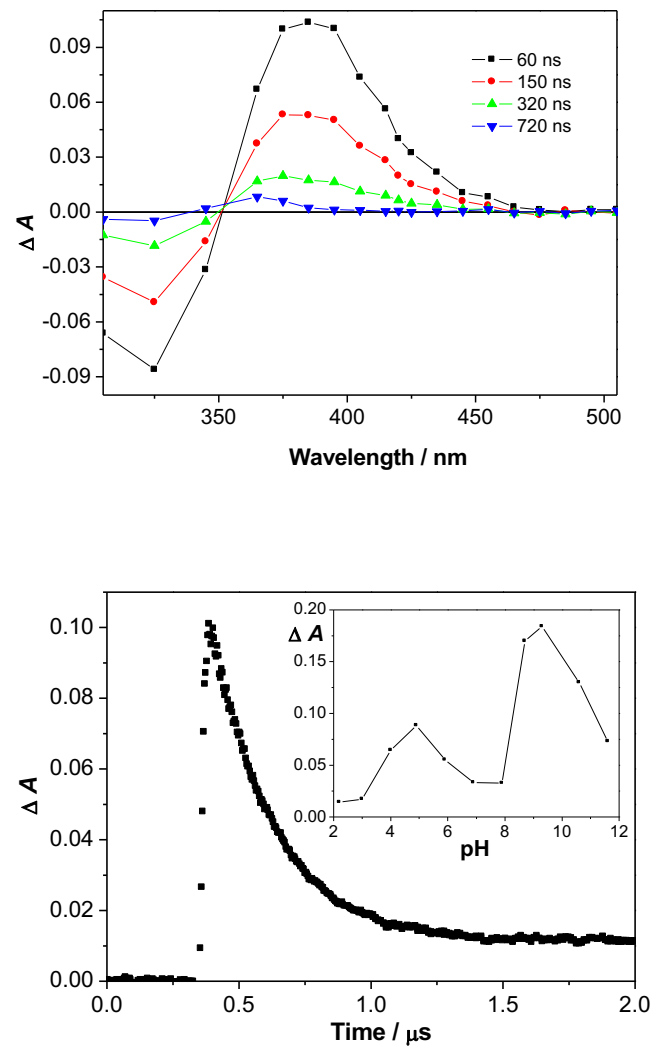

Fig. 6. Transient absorption spectra of 4 (top) in $\mathrm{CH}_{3} \mathrm{CN}-\mathrm{H}_{2} \mathrm{O}$ (5:95), and decay at $380 \mathrm{~nm}$ at $\mathrm{pH}$ $=11$. The inset shows the $\mathrm{pH}$ dependence of the transient absorbance intensity at $390 \mathrm{~nm}$, right after laser excitation).

Formation of 4-T by ESPT can only be facilitated in the $\mathrm{pH}$ range between the $\mathrm{p} K_{\mathrm{a}}{ }^{*}$ values for the pyridine protonation and the pyrrole deprotonation. These $\mathrm{p} K_{\mathrm{a}}{ }^{*}$ values were estimated in LFP experiments from the dependence of the initial transient absorption intensity right after the laser pulse collected at different $\mathrm{pH}$ values (Fig. 6 bottom, inset). Although this value is related to the formation of all transients, significantly stronger signal intensities were observed in the $\mathrm{pH}$ region between 9 and 12 where the characteristic transient assigned to 4-T was detected. Thus, the estimated $\mathrm{p} K_{\mathrm{a}}{ }^{*}$ from the LFP experiment for the pyrrole deprotonation in $\mathrm{S}_{1}$ is in the range of 
8-9, and for the protonation of the pyridine this range is between 11 and 12 (Scheme 4). The value for the pyridine $\mathrm{p} K_{\mathrm{a}}{ }^{*}$ in $\mathrm{S}_{1}$ for $\mathbf{4} \mathbf{H}^{+}$obtained by LFP (11-12) is somewhat lower than the value obtained by Förster cycle analysis (12.7). However, it should be noted that the determination of $\mathrm{p} K_{\mathrm{a}}{ }^{*}$ by Förster cycle is usually inacurrate. ${ }^{3}$ Irrespective of the accuracy for the $\mathrm{p} K_{\mathrm{a}}{ }^{*}$ values, LFP measurements clearly showed that the formation and decay kinetics of phototautomer 4-T in aqueous solution is $\mathrm{pH}$ dependent.

In some ESPT systems double proton transfer takes place through a bimolecular reaction involving two phototautomers, leading to non-exponential decays for the phototautomers. ${ }^{9}$ Therefore, the origin of the non-exponential decays for 2-T and 4-T was investigated using LFP by changing the energy of the laser pulses. For competitive uni- and bimolecular reactions, the decrease of the laser pulse energy leads to a decreased contribution of the bimolecular reaction to the observed kinetics, because the bimolecular reaction depends on the concentration of phototautomer, whereas unimolecular reactions are independent of the concentrations of reactants. The contribution of the bimolecular reaction appears as an initial non-linear decay in the semi-log plot of the kinetics (Fig. 7). Fourfold decrease of the laser pulse energy decreased the amplitude of the bimolecular contribution of the decay. This finding indicates that only one species is detected decaying by competing uni- and bimolecular reactions. Similar findings have already been reported in the photochemistry of pyridylphenols. ${ }^{70}$ 


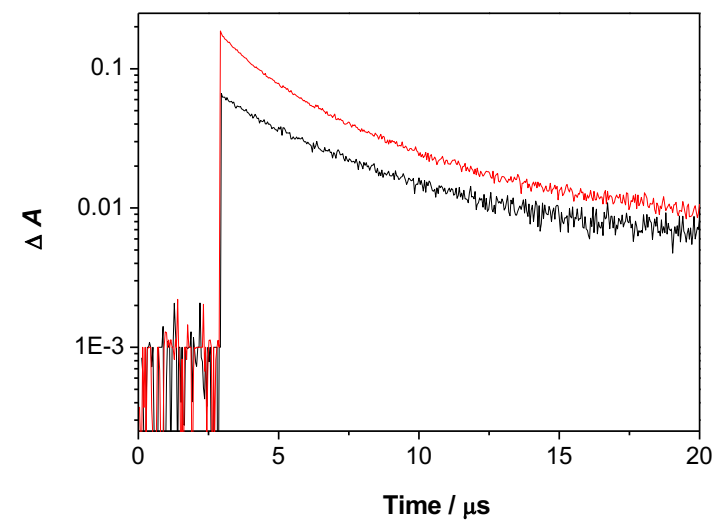

Fig. 7. Decay of the $\log$ of the transient absorbance at $400 \mathrm{~nm}$ for the solution of 4 in $\mathrm{CH}_{3} \mathrm{CN}$ $\mathrm{H}_{2} \mathrm{O}$ as a function of the relative laser pulse energy, estimated from the intensity of the benzophenone triplet at $525 \mathrm{~nm}$ (black line $\Delta A_{525}=0.08$; red line $\Delta A_{525}=0.31$ ) for optically matched solutions at the excitation wavelength $\left(A_{355}=0.31\right)$.

Proton transfer processes are usually characterized by a large primary isotope effect. ${ }^{71}$ To verify the assignment of the transient absorption to $\mathbf{2}-\mathbf{T}$ and $\mathbf{4 - T}$ we conducted LFP measurements for $\mathbf{2}$ and 4 in optically matched $\mathrm{CH}_{3} \mathrm{CN}-\mathrm{H}_{2} \mathrm{O}$ and $\mathrm{CH}_{3} \mathrm{CN}-\mathrm{D}_{2} \mathrm{O}$ solutions (Fig. 8 and Fig. S52 in the SI). Change of $\mathrm{H}_{2} \mathrm{O}$ to $\mathrm{D}_{2} \mathrm{O}$ resulted in weaker signal intensities and longer decay times for both compounds. From the ratio of the transient absorbance intensity immediately after the laser pulse the estimate for the isotope effect for the formation of tautomers is in the range 1.3.-2.5. However, the precise values of the isotope effects for the decay of transients was not warranted due to complex decay kinetics imposed by competing uni- and bimolecular reactions. The observed changes in the decay kinetics and the intensity of the transient absorption are due to the primary deuterium isotope effect for the formation and the decay of the transient species. These 
results strongly indicate that the observed transient absorption corresponds to species formed by ESPT.
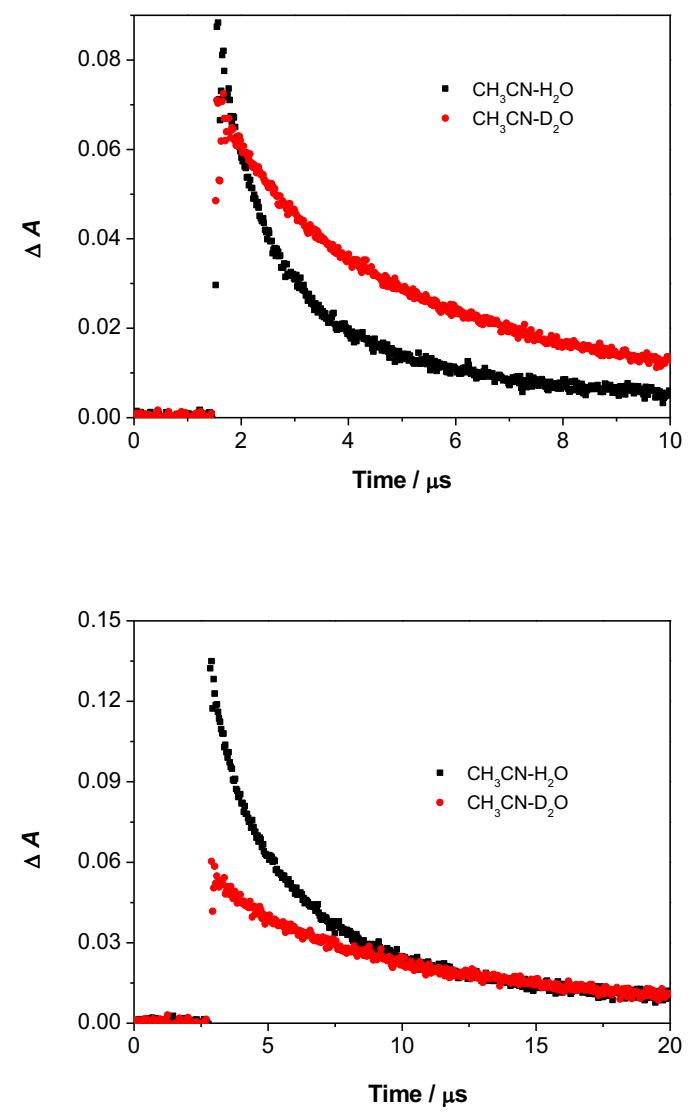

Fig. 8. Decay of transient absorbance at $420 \mathrm{~nm}$ in $\mathrm{CH}_{3} \mathrm{CN}-\mathrm{H}_{2} \mathrm{O}(1: 1)$ and $\mathrm{CH}_{3} \mathrm{CN}-\mathrm{D}_{2} \mathrm{O}(1: 1)$ for 2 (top) and 4 (bottom).

LFP measurements were also conducted for the salt of $4 \mathbf{H}^{+}$in $\mathrm{CH}_{3} \mathrm{CN}$ and $\mathrm{CH}_{3} \mathrm{CN}-\mathrm{H}_{2} \mathrm{O}$ (Fig. S53-S56 and $\mathrm{S} 57$ left). In $\mathrm{CH}_{3} \mathrm{CN}$ relatively weak transient absorption was observed with a maximum at $650 \mathrm{~nm}$. The decay was fit to a sum of two exponentials with rate constants of $5 \times$ $10^{6}$ and $2 \times 10^{4} \mathrm{~s}^{-1}$. Due to the similarity of the transient absorption with radical-cation 9 the fast component was tentatively assigned to tautomeric radical-cation 9' formed by homolytic $\mathrm{N}-\mathrm{H}$ 
cleavage of $\mathbf{4} \mathbf{H}^{+}$, whereas the slow component was assigned to radical $\mathbf{1 0}$ (Scheme 6). The measurement in $\mathrm{CH}_{3} \mathrm{CN}-\mathrm{H}_{2} \mathrm{O}$ performed at neutral or slightly basic conditions gave rise to the same transients as observed by LFP of $\mathbf{4}$ since $\mathbf{4} \mathbf{H}^{+}$at $\mathrm{pH}>5.5$ dissociates. Measurements in the acidic solutions $\left(\mathrm{H}_{2} \mathrm{SO}_{4}, \mathrm{pH} 2\right)$ gave rise to a transient absorption with a maximum at $370 \mathrm{~nm}$ and weaker signals at 390 and 420-500 nm decaying with a rate constant of $4 \times 10^{4} \mathrm{~s}^{-1}$ that in analogy was assigned to radical 10 (Fig S56 in the SI).

Scheme 6. Homolytic cleavage of $\mathbf{4} \mathbf{H}^{+}$observed in aprotic solvent.

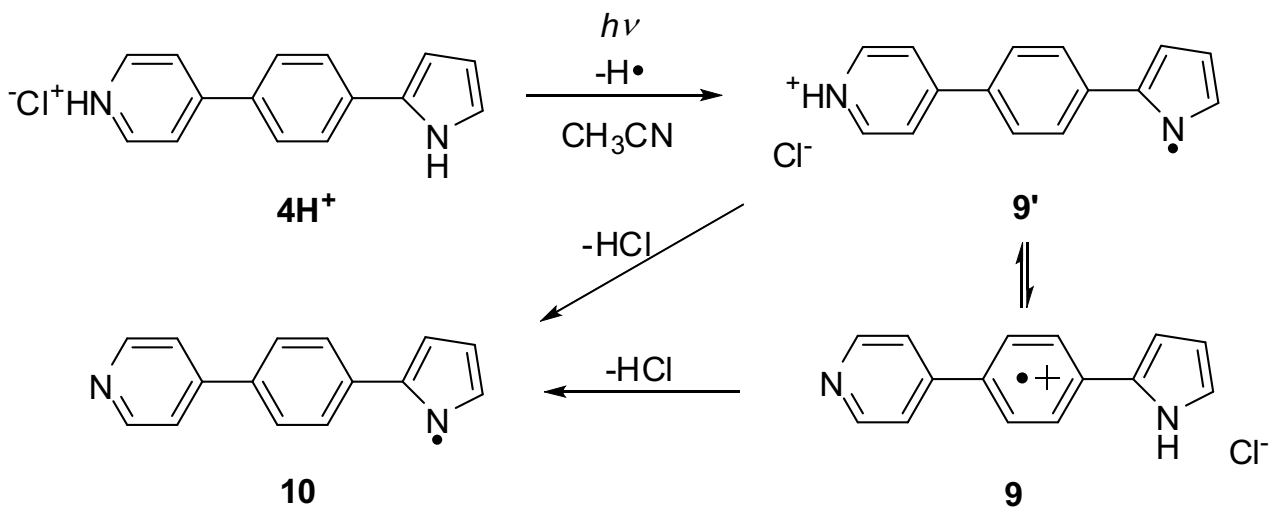

LFP experiments were conducted with the $4 \mathbf{H}^{+} \cdot \mathrm{CB}[7]$ complex to probe if the phototautomerization can take place within the cavity of $\mathrm{CB}$ [7]. Interestingly, the complexation with $\mathrm{CB}[7]$ completely changed the photochemistry of $\mathbf{4} \mathbf{H}^{+}$. The signals corresponding to the phototautomer 4-T were not detected. Instead, the transient absorption showed a maximum at $370 \mathrm{~nm}$ and a weaker broad band at 500-700 nm, similar to the transients observed in neat $\mathrm{CH}_{3} \mathrm{CN}$ after decay of the radical-cation (Fig. 9 and Fig. S58 in the SI). Therefore we assigned the observed transient absorption in the presence of $\mathrm{CB}[7]$ to the pyrrolyl radical $\mathbf{1 0}$. 


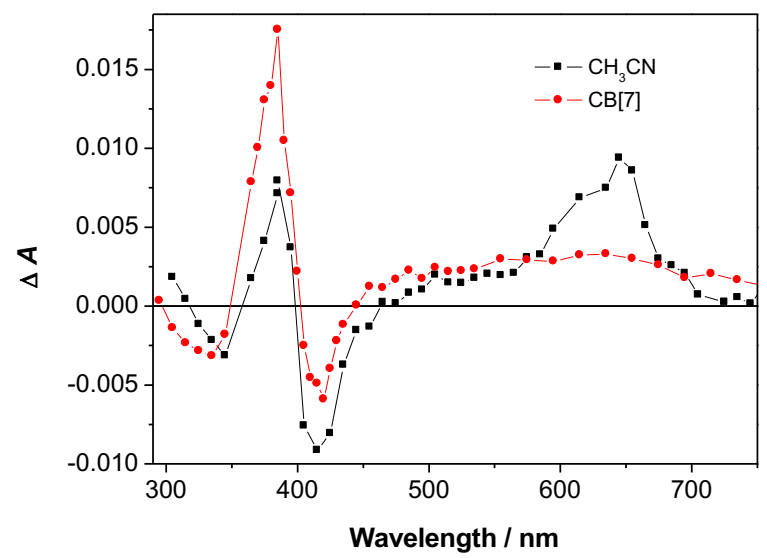

Fig. 9. Transient absorption spectra of $4 \mathbf{H}^{+}\left(4.8 \times 10^{-5} \mathrm{M}\right)$ in $\mathrm{CH}_{3} \mathrm{CN}$ and in aqueous $\mathrm{NaCl}$ in the presence of $\mathrm{CB}[7]\left(2 \times 10^{-4} \mathrm{M}\right)$ taken $700 \mathrm{~ns}$ after the laser pulse. The solutions were optically matched $\left(A_{355}=0.35\right)$.

\section{Discussion}

Irradiation of 2-4 does not yield any stable photoproduct. However, quenching of fluorescence in aqueous solutions and LFP measurements indicate that ESPT takes place in $\mathrm{H}_{2} \mathrm{O}$ leading to the formation of phototautomers. Since the acidic site (pyrrole) and the basic site (pyridine) are not in proximity, a polar protic solvent is essential to stabilize the CT-character of the $\mathrm{S}_{1}$ state, and even more important, to act as a proton donor (acid) and acceptor (base).

Formation of phototautomer 2-T from the ortho derivative in aqueous solution was assigned to the transient absorption with maximum at $390 \mathrm{~nm}$. In near-neutral solution the decay for $\mathbf{2 - T}$ was not exponential due to competing uni- and bimolecular reactions, as indicated by the dependence of the kinetics on the laser pulse energy. Only an estimate was possible for the decay time of 2$\mathbf{T}, \tau \approx 1.5 \mu \mathrm{s}$. The assignment of the transient to $2-\mathbf{T}$ was corroborated by a primary isotope 
effect in $\mathrm{D}_{2} \mathrm{O}$ solutions for its formation and decay (Fig 8). Moreover, 2-T can in principle exist in two isomeric forms (2-Ta and 2-Tb, Scheme 7). The observed non-exponential decay of 2-T could in principle originate from the presence of these two isomers that undergo photochemical $E-Z$ isomerization, and are characterized by different decay rate constants. However, the photochemical E-Z-isomerization would require a second photon. Furthermore, we observe similar non-exponential decay kinetics for 4-T which cannot have two stereoisomers. Since the fast decay depends largely on the laser pulse energy, this kinetics is more likely due to the bimolecular reaction of 2-T involving two proton transfers.

Scheme 7. Phototautomerization of 2.

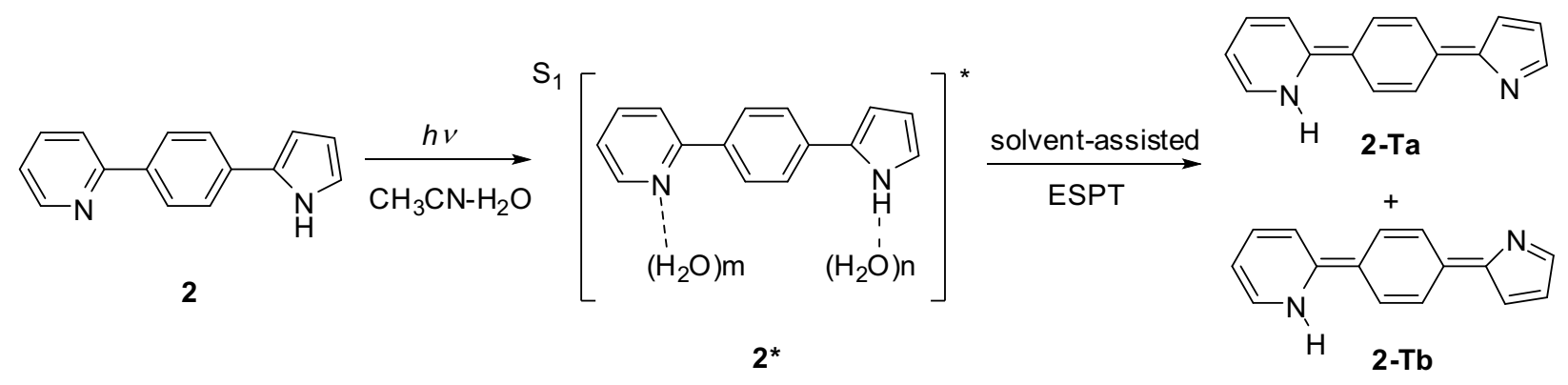

Meta derivative 3 also bears the basic pyridine nitrogen and the acidic pyrrole NH. Strong quenching of fluorescence in aqueous solution strongly indicates deactivation from $\mathrm{S}_{1}$ by ESPT. Contrary to the transient spectra of 2, the LFP for the meta isomer 3 did not give rise to a characteristic transient absorption that could be assigned to the phototautomer (Fig. S42 in the SI). Instead, in aqueous solution the transient absorption spectrum was narrower (370-390 nm), and the kinetics was slower than for $\mathbf{2 - T}$, that is the fast decay was missing. The spectrum for the photolysis of 3 was assigned to pyrrolyl radical 10 (Fig. 5 bottom). We do not have data for the 
acidity/basicity of $\mathbf{3}$ in $S_{1}$ or spectroscopic evidence for the formation of the corresponding phototautomer 3-T. Nevertheless, 3-T is a zwitterion that cannot be represented by a Kekulé structure. Therefore, if this transient was formed in aqueous solution it would probably be very short-lived (probably in the picosecond time-scale) and could not be detected by nanosecond LFP. However, structurally related more stable zwitterions formed in photodehydration of phenols have been reported and characterized by LFP. ${ }^{72}$ The other plausible explanation for the observed quenching of fluorescence of $\mathbf{3}$ in aquoeus solution does not involve ESPT and formation of phototautomer 3-T. Quenching may occur due to H-bonding with the solvent, leading to a de-excitation via an internal conversion channel. ${ }^{34,35,36}$

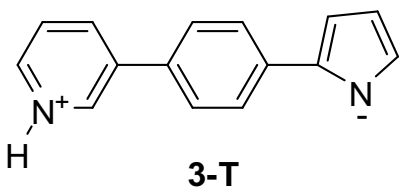

Excitation of 4 to $\mathrm{S}_{1}$ leads to a significant enhancement of the pyridine basicity ( $\mathrm{p} K_{\mathrm{a}} * \approx 12$ ), as indicated by fluorescence measurements. In addition, concomitant enhancement of the pyrrole acidity in aqueous solution leads to ESPT and formation of phototautomer 4-T, providing that the solution $\mathrm{pH}$ is in the range between the $\mathrm{p} K_{\mathrm{a}}{ }^{*}$ of pyrrole $(\mathrm{pH} \approx 8-9)$, and the $\mathrm{p} K_{\mathrm{a}}{ }^{*}$ of pyridine $(\mathrm{pH} \approx 11-12)$. A water molecule protonates the pyridine nitrogen and the pyrrole is deprotonated to another water molecule from the solvent leading to the formation of phototautomer 4-T. Therefore, in the appropriate $\mathrm{pH}$ range phototautomer 4-T was detected by LFP by its characteristic strong transient absorption with a maximum at $390 \mathrm{~nm}$. Phototautomer 4-T in nearneutral solution ( $\mathrm{pH}$ 8-10) decays through uni- and bimolecular reactions, as indicated by the 
dependence of decay on the laser pulse energy. As anticipated the formation and decay of 4-T is $\mathrm{pH}$ dependent and susceptible to deuterium isotope effect. The decay kinetics for 4-T is probably governed by general and specific acid and base catalysis. Such acid/base catalysis was demonstrated for example in the hydration reactions of quinone methides, ${ }^{73}$ or keto-enol tautomerisations. $^{74,75}$

The driving force for the formation of phototautomer 4-T was investigated by molecular modeling. The energy for the vertical excitation of 4 to $S_{1}$ calculated at the B3LYP/6-311G level of theory in the gas phase is $366 \mathrm{kJmol}^{-1}$ (Table S1 in the SI), which perfectly matches the experimentally observed absorption of 4 in $\mathrm{CH}_{3} \mathrm{CN}\left(\lambda_{\max }=327 \mathrm{~nm}, 365.8 \mathrm{kJmol}^{-1}\right)$. The $\mathrm{S}_{1}$ state of $\mathbf{4}$ has a significant CT character, as evidenced by the fluoro-solvatochromic properties and the calculated dipole moment (Table S3 in th SI). The CT character is the driving force for ESPT to occur. The calculated energy of the $\mathrm{S}_{1}$ state of 4-T in the gas phase is higher, $390 \mathrm{kJmol}^{-1}$ (Fig. S3 and S4, and Tables S2, and S5 in the SI). However, we have no evidence that 4-T is formed in the excited state. Its formation may involve double ESPT by solvent molecules in an adiabatic exergonic reaction, or passing through a conical intersection, leading to 4-T in $\mathrm{S}_{0}$. 
Scheme 8. Energy diagram for $\mathbf{4}$ and 4-T.

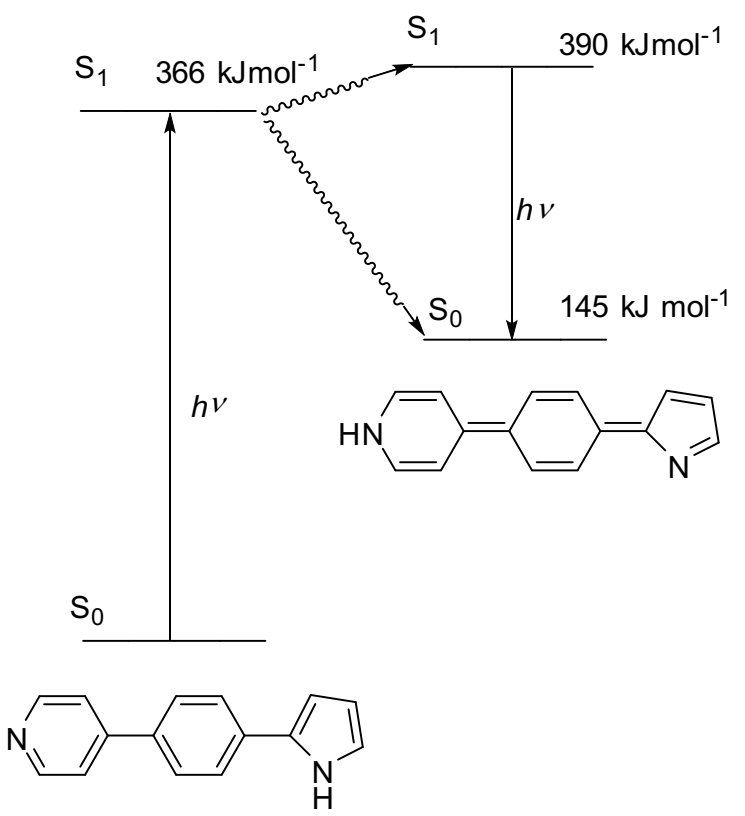

Kinetics for 4-T formation could not be studied since the tautomerization takes place within the laser pulse (10 ns). Protonation and deprotonation may take place simultaneously, or sequentially. Furthermore, we have no experimental evidence if the tautomerization involves a $\mathrm{H}_{2} \mathrm{O}$-relay mechanism as was suggested for 7 -azaindoles ${ }^{18}$ and 7 -hydroxyquinoline. . $^{1920,21,22,23}$ Phototautomer 4-T is $145 \mathrm{kJmol}^{-1}$ higher in energy than 4, which sets the stage for the tautomerization in the ground state back to the starting molecule, taking place between 200 ns to $4 \mu \mathrm{s}$, depending on the $\mathrm{pH}$ of the solution.

In an aprotic solvent, excitation of $\mathbf{4}$ to $\mathrm{S}_{1}$ leads to parallel reactions, where homolytic cleavage of the pyrrole $\mathrm{N}-\mathrm{H}$ forms radical 10, and photoionization of $\mathbf{4}$ forms radical-cation $\mathbf{9}$. The radical-cation is acidic and deprotonates to pyrrolyl radical $\mathbf{1 0}$. Similarly, excitation of $\mathbf{4} \mathbf{H}^{+}$in an aprotic solvent ultimately leads to the formation of 10, involving homolytic cleavage of the pyrrole N-H bond to form radical-cation 9' followed by deprotonation to 10. These processes probably take place also in aqueous solution, but with a quantum efficiency significantly lower 
than for the phototautomerization. Therefore, radical $\mathbf{1 0}$ can be detected by LFP after the decay of 4-T. However, the minor pathways involving homolytic cleavage leading to radicals $\mathbf{1 0}$ become dominant in acidic aqueous solutions at $\mathrm{pH}<\mathrm{p} K_{\mathrm{a}} *$ for the deprotonation of pyrrole in $\mathrm{S}_{1}$. Positively charged $\mathbf{4} \mathbf{H}^{+}$formed a stable host-guest complex with $\mathrm{CB}[7]$ with a $\beta_{11}$ value of (1.0 \pm $0.2) \times 10^{5} \mathrm{M}^{-1}$. Stabilization of the positive charge in the complex increased the $\mathrm{p} K_{\mathrm{a}}$ value of the pyridine nitrogen, and presumably decreased the pyrrole acidity. Therefore, within the cavity of $\mathrm{CB}$ [7] the pyrrole $\mathrm{NH}$ in $\mathbf{4} \mathbf{H}^{+}$cannot deprotonate to give phototautomer $\mathbf{4 - T}$. Instead, the competitive homolytic N-H bond cleavage ultimately leading to the formation of pyrrolyl radical 10 becomes the dominant photochemical process (as presented in Scheme 6). Consequently, the complexation with $\mathrm{CB}[7]$ fundamentally changes the reactivity of the molecule so that instead of proton transfer it undergoes homolytic cleavage.

The results presented herein have demonstrated the operation of $\mathrm{H}_{2} \mathrm{O}$-mediated long-range ESPT in terphenyl derivatives $\mathbf{2 - 4}$. The ability to control this process by $\mathrm{pH}$ and complexation with $\mathrm{CB}[7]$ is of particular importance. It implicates the use of the investigated systems for the rational design of functional molecules with potential applications in different research fields such as photochemical switching, drug delivery vehicles, logic gates, sensing, operation of proton pumps in biological systems, where the photochemistry of these terphenyl derivatives can be modulated by changes in $\mathrm{pH}$ or complexation to supramolecular hosts.

\section{Conclusion}

Pyrrolylphenylpyridine terphenyl derivatives 2-4 were synthesized and their photophysical properties and photochemical reactivity in phototautomerization reactions was investigated. On excitation to $S_{1}$ in polar protic solvents, 2-4 populate CT states leading to the enhanced basicity 
of pyridine and enhanced acidity of pyrrole. The difference in acid-base properties enables excited state proton transfer (ESPT) giving rise to phototautomers 2-T, 3-T and 4-T. Phototautomers 2-T and 4-T were detected by LFP by their characteristic strong transient absorption at 380-450 nm, whereas zwitterionic 3-T formed from the meta-derivative could not be detected probably due to its short lifetime. The decays for 2-T and 4-T were non-exponential due to competing mono- and bimolecular reactions. The estimated lifetimes for 2-T and 4-T are $1.5 \mu \mathrm{s}$, and $4 \mu \mathrm{s}$ at $\mathrm{pH} 9$ and a shortening of the lifetime of 4-T was observed at higher $\mathrm{pH}$ values. The pyridinium salt $\mathbf{4} \mathbf{H}^{+}$forms a stable complex with $\mathrm{CB}$ [7] with 1:1 stoichiometry $\left(\beta_{11}\right.$ of $\left.(1.0 \pm 0.2) \times 10^{5} \mathrm{M}^{-1}\right)$. The complexation increases the $\mathrm{p} K_{\mathrm{a}}$ of $\mathbf{4}$ and changes its photochemical reactivity. Due to decreased acidity of the pyrrole phototautomerization in the inclusion complex, the formation of the tautomer does not take place but homolytic cleavage of the pyrrole $\mathrm{NH}$ leads to the formation of radicals, as is also observed in non-protic polar solvents.

\section{Experimental section}

\section{General}

${ }^{1} \mathrm{H}$ and ${ }^{13} \mathrm{C}$ NMR spectra were recorded at 300 , or $600 \mathrm{MHz}$ at $\mathrm{rt}$ using TMS as a reference and chemical shifts were reported in ppm. Melting points were determined using a Mikroheiztisch apparatus and were not corrected. IR spectra were recorded on a spectrophotometer in $\mathrm{KBr}$ and the characteristic peak values were given in $\mathrm{cm}^{-1}$. HRMS were obtained on a MALDI TOF/TOF instrument. Irradiation experiments were performed in a reactor equipped with 16 lamps with the output at $350 \mathrm{~nm}$ or a reactor equipped with 8 lamps. During the irradiations, the irradiated solutions were continuously purged with $\mathrm{Ar}$ and cooled by a tap-water finger-condenser. 
Solvents for irradiations were of HPLC purity. Chemicals were purchased from the usual commercial sources and were used as received. Solvents for chromatographic separations were used as they are delivered from supplier (p.a. grade) or purified by distillation $\left(\mathrm{CH}_{2} \mathrm{Cl}_{2}\right)$. Calculations were performed using Gaussian 03 software. ${ }^{76}$

\section{2-(4-Bromophenyl)pyridine (6) $)^{44,45}$}

In a refluxing solution of 2-bromopyridine $\quad\left(\begin{array}{lllll}960 & \mathrm{mg}, & 6.0 & \mathrm{mmol}\end{array}\right)$ and tetrakis(triphenylphosphine)palladium(0) $(80 \mathrm{mg}, 0.07 \mathrm{mmol})$ in dioxane $(20 \mathrm{~mL})$, a solution of p-bromophenylboronic acid $(\mathbf{5}, 660 \mathrm{mg}, 3.3 \mathrm{mmol})$ in aqueous $\mathrm{K}_{2} \mathrm{CO}_{3}(20 \mathrm{~mL}, 2 \mathrm{M})$ was added dropwise during $8 \mathrm{~h}$ under nitrogen. After additional $8 \mathrm{~h}$ of reflux, the reaction was quenched with $\mathrm{H}_{2} \mathrm{O}(50 \mathrm{~mL})$ and extracted with $\mathrm{CH}_{2} \mathrm{Cl}_{2}(3 \times 30 \mathrm{~mL})$. The extracts were dried over anhydrous $\mathrm{MgSO}_{4}$, filtered and the solvent was removed on a rotational evaporator. The crude compound was purified using silica column chromatography with $\mathrm{CH}_{2} \mathrm{Cl}_{2} / \mathrm{EtOAc}$ (1:1), which afforded pure compound (405 mg, $29 \%$ ).

Colorless oil; ${ }^{1} \mathrm{H}$ NMR $\left(\mathrm{CDCl}_{3}, 300 \mathrm{MHz}\right)$ 8/ppm 8.68 (ddd, $\left.1 \mathrm{H}, J=1.0,1.6,4.8 \mathrm{~Hz}\right), 7.87$ (d, $2 \mathrm{H}, J=8.6 \mathrm{~Hz}), 7.75(\mathrm{ddd}, 1 \mathrm{H}, J=1.6,8.0,7.0 \mathrm{~Hz}), 7.69(\mathrm{ddd}, 1 \mathrm{H}, J=1.0,1.6,8.0 \mathrm{~Hz}), 7.59(\mathrm{~d}$, $2 \mathrm{H}, J=8.6 \mathrm{~Hz}), 7.24(\mathrm{ddd}, 1 \mathrm{H}, J=1.6,4.8,6.2 \mathrm{~Hz})$.

\section{3-(4-bromophenyl)pyridine (7) ${ }^{49,50}$}

A solution of 3-pyridineboronic acid (200 mg, $1.62 \mathrm{mmol}), p$-dibromobenzene (766 mg, 1.63 $\mathrm{mmol})$ and tetrakis(triphenylphosphine)palladium(0) (40 mg, $0.035 \mathrm{mmol})$ in dioxane $(20 \mathrm{~mL})$ and aqueous $\mathrm{K}_{2} \mathrm{CO}_{3}(20 \mathrm{~mL}, 2 \mathrm{M})$ was refluxed for $16 \mathrm{~h}$ under nitrogen. The reaction mixture was quenched with $\mathrm{H}_{2} \mathrm{O}(50 \mathrm{~mL})$ and extracted with $\mathrm{CH}_{2} \mathrm{Cl}_{2}(3 \times 30 \mathrm{~mL})$. The organic layer was 
dried over magnesium sulfate, filtered and evaporated. The extracts were dried over anhydrous $\mathrm{MgSO}_{4}$, filtered and the solvent was removed on a rotational evaporator. The crude compound was purified using silica column chromatography with $\mathrm{CH}_{2} \mathrm{Cl}_{2} / \mathrm{EtOAc}$ (1:1), which afforded the pure compound ( $290 \mathrm{mg}, 76 \%)$.

Colorless oil; ${ }^{1} \mathrm{H}$ NMR $\left(\mathrm{CDCl}_{3}, 300 \mathrm{MHz}\right) \delta / \mathrm{ppm} 8.81(\mathrm{~d}, 1 \mathrm{H}, J=2.2 \mathrm{~Hz}), 8.61(\mathrm{dd}, 1 \mathrm{H}, J=1.6$, $4.8 \mathrm{~Hz}), 7.83$ (ddd, $1 \mathrm{H}, J=2.2,4.0,8.0 \mathrm{~Hz}), 7.61(\mathrm{~d}, 2 \mathrm{H}, J=8.4 \mathrm{~Hz}), 7.44(\mathrm{~d}, 2 \mathrm{H}, J=8.4 \mathrm{~Hz}$ ), $7.36(\mathrm{dd}, 1 \mathrm{H}, J=4.9,8.0 \mathrm{~Hz})$.

\section{4-(4-bromophenyl)pyridine $(8)^{48}$}

Solution of dry pyridine $(0.8 \mathrm{~mL}, 10 \mathrm{mmol})$ in dry ether $(100 \mathrm{~mL})$ was cooled to $0{ }^{\circ} \mathrm{C}$ under nitrogen and trifluoromethylsulfonic anhydride $(1.68 \mathrm{~mL}, 10 \mathrm{mmol})$ was added dropwise with vigorous stirring. The resulting mixture was stirred for $30 \mathrm{~min}$ and then cooled to $-78{ }^{\circ} \mathrm{C}$. In another flask $p$-dibromobenzene $(2.36 \mathrm{~g}, 10 \mathrm{mmol})$ was dissolved in dry ether $(15 \mathrm{~mL})$ under nitrogen and cooled to $-78^{\circ} \mathrm{C}$. A solution of n-butyllithium $(2.5 \mathrm{M}, 5.2 \mathrm{~mL})$ was added dropwise. The resulting organolithium reagent was cannulated to the flask containing pyridine triflate with vigorous stirring during $10 \mathrm{~min}$, and the mixture was left to warm to $\mathrm{rt}$. The reaction was quenched with aqueous $\mathrm{NaOH}(100 \mathrm{~mL}, \mathrm{w}=5 \%)$ and stirred for $10 \mathrm{~min}$. The organic layer was separated, dried over sodium carbonate and filtered. Evaporation of the solvent afforded crude 4(4-bromophenyl)-1-(trifluoromethylsulfonyl)-1,4-dihydropyridine that was purified on a silica column with hexane/ $\mathrm{CH}_{2} \mathrm{Cl}_{2}$ (1:1). The isolated compound was stirred for $12 \mathrm{~h}$ in a mixture of dioxane $(20 \mathrm{~mL})$ and aqueous $\mathrm{NaOH}(20 \mathrm{~mL}, \mathrm{w}=20 \%)$. After dilution with $\mathrm{H}_{2} \mathrm{O}$ the compound was extracted with $\mathrm{CH}_{2} \mathrm{Cl}_{2}(3 \times 30 \mathrm{~mL})$. The extracts were dried over anhydrous $\mathrm{MgSO}_{4}$, filtered 
and the solvent was removed on a rotational evaporator to afford the pure compound (585 mg, 25 $\%)$.

Pale yellow crystals; ${ }^{1} \mathrm{H}$ NMR $\left(\mathrm{CDCl}_{3}, 300 \mathrm{MHz}\right) \delta / \mathrm{ppm} 8.66(\mathrm{~d}, 2 \mathrm{H}, J=6.3 \mathrm{~Hz}), 7.61(\mathrm{~d}, 2 \mathrm{H}, J$ $=8.6 \mathrm{~Hz}), 7.50(\mathrm{~d}, 2 \mathrm{H}, J=8.6 \mathrm{~Hz}), 7.46(\mathrm{~d}, 2 \mathrm{H}, J=6.3 \mathrm{~Hz})$.

\section{General procedure for the Suzuki coupling and the Boc-deprotection}

In a refluxing mixture of bromophenylpyridine $(1.9$ mmol), tetrakis(triphenylphosphine)palladium $(0)(0.095 \mathrm{mmol})$ and cesium carbonate $(3.78 \mathrm{mmol})$ in toluene $(40 \mathrm{~mL})$ under argon, a solution of $N$-Boc-2-pyrrolboronic acid $(1.9 \mathrm{mmol})$ was added dropwise during $8 \mathrm{~h}$. After addition the resulting solution was refluxed for additional $2 \mathrm{~h}$ and then stirred at rt overnight. The reaction was quenched with $\mathrm{H}_{2} \mathrm{O}(50 \mathrm{~mL})$, the organic layer was separated and the aqueous layer extracted with $\mathrm{CH}_{2} \mathrm{Cl}_{2}(3 \times 30 \mathrm{~mL})$. The combined organic extracts were dried over anhydrous $\mathrm{MgSO}_{4}$, filtered and the solvent was removed on a rotational evaporator. To the resulting crude compound, a solution of sodium methoxide prepared from sodium (400 $\mathrm{mg}, 17.3 \mathrm{mmol})$ and methanol $(100 \mathrm{~mL})$ was added and the mixture was refluxed under nitrogen for $3 \mathrm{~h}$. The solvent was evaporated, $\mathrm{H}_{2} \mathrm{O}(50 \mathrm{~mL})$ was added and extraction with $\mathrm{CH}_{2} \mathrm{Cl}_{2}(3 \times 30 \mathrm{~mL})$ was carried out. The combined organic extracts were washed with brine, dried over anhydrous $\mathrm{MgSO}_{4}$, filtered and the solvent was removed on a rotational evaporator. The crude compound was purified using silica column chromatography with $\mathrm{EtOAc} / \mathrm{CH}_{2} \mathrm{Cl}_{2}$ (1:4) as eluent.

\section{2-(4-(1H-pyrrol-2-yl)phenyl)pyridine (2)}


In a reaction of 2-(4-bromophenyl)pyridine $\quad(6,250 \quad \mathrm{mg}, \quad 1.1 \quad \mathrm{mmol})$, tetrakis(triphenylphosphine)palladium $(0)(90 \mathrm{mg}, 0.08 \mathrm{mmol})$ and cesium carbonate $(750 \mathrm{mg}$, $2.3 \mathrm{mmol}) \mathrm{N}$-Boc-2-pyrrolboronic acid $(240 \mathrm{mg}, 1.0 \mathrm{mmol})$ the crude compound was obtained. After refluxing with sodium methoxide prepared with sodium (380 mg, $16 \mathrm{mmol})$ and column chromatography the pure compound was obtained (60 mg, $26 \%$ ).

Colorless crystals, ${ }^{1} \mathrm{H}$ NMR $\left(\mathrm{C}_{6} \mathrm{D}_{6}, 300 \mathrm{MHz}\right) \delta / \mathrm{ppm} 8.62(\mathrm{~d}, 1 \mathrm{H}, J=4.7 \mathrm{~Hz}), 8.17(\mathrm{~d}, 2 \mathrm{H}, J=$ $8.5 \mathrm{~Hz}), 7.41$ (br s, 1H), 7.38 (d, 1H, $J=7.9 \mathrm{~Hz}), 7.29$ (d, 2H, $J=8.5 \mathrm{~Hz}), 7.14$ (dd, 1H, $J=1.5$, $7.9 \mathrm{~Hz}), 6.67$ (ddd, 1H, $J=1.2,4.7,7.9 \mathrm{~Hz}), 6.64-6.61(\mathrm{~m}, 1 \mathrm{H}), 6.44-6.41(\mathrm{~m}, 1 \mathrm{H}), 6.37-6.32$

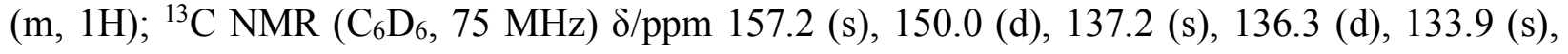
131.7 (s), 127.7 (d), 124.2 (d), 121.8 (d), 119.7 (d), 119.4 (d), 110.5 (d), 107.2 (d).

\section{3-(4-(1H-pyrrol-2-yl)phenyl)pyridine (3)}

In a reaction of 3-(4-bromophenyl)pyridine $\quad(7, \quad 280 \quad \mathrm{mg}, \quad 1.2 \quad \mathrm{mmol})$, tetrakis(triphenylphosphine)palladium(0) $(70 \mathrm{mg}, 0.06 \mathrm{mmol})$, cesium carbonate $(780 \mathrm{mg}, 2.4$ mmol) and $N$-Boc-2-pyrrolboronic acid (250 mg, $1.0 \mathrm{mmol}$ ) crude compound was obtained. After refluxing with sodium methoxide prepared with sodium (380 $\mathrm{mg}, 16 \mathrm{mmol})$ and column chromatography the pure compound was obtained (50 mg, $23 \%$ ).

Colorless crystals; $\mathrm{mp}=174-176^{\circ} \mathrm{C}$; IR $\left(\mathrm{cm}^{-1}, \mathrm{KBr}\right) 3402,3135,1607,1480,1416,1106,843$, 792, 728; ${ }^{1} \mathrm{H}$ NMR $\left(\mathrm{C}_{6} \mathrm{D}_{6}, 300 \mathrm{MHz}\right) \delta / \mathrm{ppm} 9.00(\mathrm{~d}, 1 \mathrm{H}, J=2,1 \mathrm{~Hz}), 8.54(\mathrm{dd}, 1 \mathrm{H}, J=1.5,4.7$ Hz), 7.58-7.44 (m, 1H), $7.41(\mathrm{~d}, 1 \mathrm{H}, J=8.4 \mathrm{~Hz}), 7.27$ (d, 2H, $J=8.2 \mathrm{~Hz}), 7.19$ (d, 2H, $J=8.2$ $\mathrm{Hz}), 6.80(\mathrm{dd}, 1 \mathrm{H}, J=4.7,7.6 \mathrm{~Hz}), 6.65-6.59(\mathrm{~m}, 1 \mathrm{H}), 6.48-6.43(\mathrm{~m}, 1 \mathrm{H}), 6.39-6.33(\mathrm{~m} 1 \mathrm{H}) ;{ }^{13} \mathrm{C}$

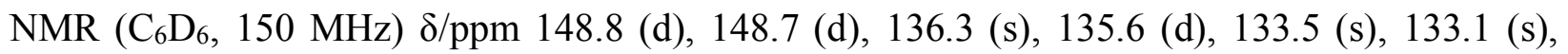


131.5 (s), 124.6 (d), 123.5 (d), 119.5 (d), 110.6 (d), 107.1 (d); HRMS (MALDI-TOF): m/z [M + e] $]^{-}$calcd for $\left(\mathrm{C}_{15} \mathrm{H}_{12} \mathrm{~N}_{2}\right)^{-} 220.0995$; found 220.0990 .

\section{4-(4-(1H-pyrrol-2-yl)phenyl)pyridine (4)}

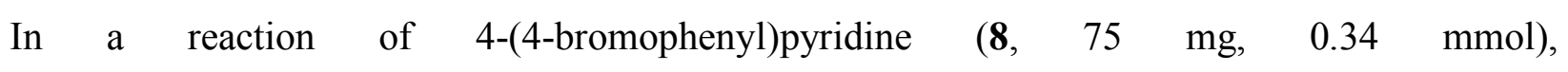
tetrakis(triphenylphosphine)palladium(0) (40 mg, $0.034 \mathrm{mmol})$, cesium carbonate (220 mg, 0.68 mmol) and $N$-Boc-2-pyrrolboronic acid $(72 \mathrm{mg}, 0.30 \mathrm{mmol})$ crude compound was obtained. After preparative TLC on silica and ethyl-acetate/dichloromethane (1:4) as eluent, the compound was refluxed with sodium methoxide prepared with sodium (380 $\mathrm{mg}, 16 \mathrm{mmol})$ and column chromatography the pure compound was obtained (52 mg, $74 \%$ ).

Pale yellow crystals; $\mathrm{mp}=170-172{ }^{\circ} \mathrm{C}$; IR $\left(\mathrm{cm}^{-1}, \mathrm{KBr}\right) 3122,1593,1488,1413,1283,1222$, 1116, 992, 818, 726; ${ }^{1} \mathrm{H}$ NMR $\left(\mathrm{CDCl}_{3}, 300 \mathrm{MHz}\right) \delta / \mathrm{ppm} 8.65(\mathrm{~d}, 2 \mathrm{H}, J=6.2 \mathrm{~Hz}), 8.62-8.53(\mathrm{~m}$, 1H), $7.66(\mathrm{~d}, 2 \mathrm{H}, J=8.4 \mathrm{~Hz}), 7.58(\mathrm{~d}, 2 \mathrm{H}, J=8.4 \mathrm{~Hz}), 7.52(\mathrm{~d}, 2 \mathrm{H}, J=6.2 \mathrm{~Hz}), 6.94-6.90(\mathrm{~m}$, 1H), 6.64-6.60 (m, 1H), 6.36-6.31 (m, 1H); ${ }^{13} \mathrm{C} \mathrm{NMR}\left(\mathrm{CDCl}_{3}, 75 \mathrm{MHz}\right) \delta / \mathrm{ppm} 150.2(\mathrm{~d}), 147.6$ (s), 135.3 (s), 133.4 (s), 131.1 (s), 127.4 (d), 124.2 (d), 121.1 (d), 119.4 (d), 110.4 (d), 106.8 (d); HRMS (MALDI-TOF): $\mathrm{m} / \mathrm{z}[\mathrm{M}+\mathrm{H}]^{+}$calcd for $\left(\mathrm{C}_{15} \mathrm{H}_{13} \mathrm{~N}_{2}\right)^{+}$221.1073; found 221.1074.

By adding an etheral solution of $\mathrm{HCl}$ to the solution of $\mathbf{4}$ in dry ether, the hydrochloride salt $\mathbf{4} \mathbf{H}^{+}$ precipitated quantitatively. The salt was filtered and washed with ether affording yellow-green crystals; $\mathrm{mp}=186-188^{\circ} \mathrm{C}$; IR $\left(\mathrm{cm}^{-1}, \mathrm{KBr}\right) 3415,3250,1633,1601,1481,1297,1125,802 ;{ }^{1} \mathrm{H}$ NMR (DMSO-d 6 , $300 \mathrm{MHz}) \delta / \mathrm{ppm} 11.56(\mathrm{~s}, 1 \mathrm{H}), 8.85(\mathrm{~d}, 2 \mathrm{H}, J=6.0 \mathrm{~Hz}), 8.33(\mathrm{~d}, 2 \mathrm{H}, J=6.0$ $\mathrm{Hz}), 8.05(\mathrm{~d}, 2 \mathrm{H}, J=8.2 \mathrm{~Hz}), 7.85(\mathrm{~d}, 2 \mathrm{H}, J=8.2 \mathrm{~Hz}), 7.00-6.94(\mathrm{~m}, 1 \mathrm{H}), 6.79-6.72(\mathrm{~m}, 1 \mathrm{H})$,

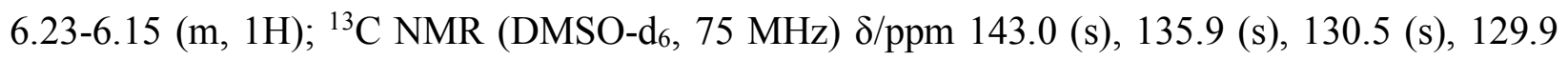
(s), 128.4 (d), 123.9 (d), 122.4 (d), 121.1 (d), 109.7 (d), 107.9 (d). 


\section{Steady-State and Time-Resolved Fluorescence Measurements}

Steady-state measurements were performed with a QM-2 fluorimeter (PTI). The samples were dissolved in cyclohexane, $\mathrm{CH}_{3} \mathrm{CN}$, or $\mathrm{CH}_{3} \mathrm{CN}-\mathrm{H}_{2} \mathrm{O}$ (1:1) and the concentrations were adjusted to absorbances of less than 0.1 at the excitation wavelengths of 310,320 , or $330 \mathrm{~nm}$. Solutions were purged with nitrogen for 30 min prior to analysis. Measurements were performed at $20{ }^{\circ} \mathrm{C}$. Fluorescence quantum yields were determined by comparison of the integral of the emission bands with the one of quinine sulfate in $0.05 \mathrm{M}$ aqueous $\mathrm{H}_{2} \mathrm{SO}_{4}\left(\Phi_{\mathrm{f}}=0.53\right){ }^{52}$ For $\mathbf{4} \mathbf{H}^{+}$, acridine yellow in $\mathrm{CH}_{3} \mathrm{OH}$ was used as a reference $\left(\Phi_{\mathrm{f}}=0.57\right){ }^{53}$ Typically, three absorption traces were recorded (and averaged) and three fluorescence emission traces were collected by exciting the sample at three different wavelengths. Three quantum yields were calculated (eq. S1 in the SI) and the mean value was reported.

Fluorescence decays, collected over 1023 time channels, were obtained on an Edinburgh Instruments OB920 single photon counter using light emitting diodes for excitation (excitation wavelength $335 \mathrm{~nm}$, or $310 \mathrm{~nm}$ for cyclohexane solutions). The instrument response functions (using LUDOX scatterer) were recorded at the same wavelengths as the excitation wavelength and had a half width of $\approx 0.2 \mathrm{~ns}$. Emission decays for samples in $\mathrm{CH}_{3} \mathrm{CN}$ solutions were recorded at 410,430 , and $450 \mathrm{~nm}$, while in cyclohexane solutions the decays were measured at 360,370 and $390 \mathrm{~nm}$. The counts in the peak channel were $3 \times 10^{3}$. For aqueous solutions, the decays were collected at 450 and $470 \mathrm{~nm}$ until they reached $1 \times 10^{3}$ counts in the peak channel. The time increment per channel was 0.01753 ns. Obtained histograms were fit as sums of exponentials using global Gaussian-weighted non-linear least-squares fitting based on Marquardt-Levenberg 
minimization implemented in the Fast software package from Edinburgh Instruments. The fitting parameters (decay times and pre-exponential factors) were determined by minimizing the global reduced chi-square $\chi^{2}$ and graphical methods were used to judge the quality of the fit that included plots of the weighted residuals vs. channel number.

\section{Determination of $\mathrm{p} K_{\mathrm{a}}$ and $\mathrm{p} K_{\mathrm{a}}$ * for $2-4$}

\section{UV-vis titration}

A stock solution of $\mathbf{4} \mathbf{H}^{+}(1.35 \mathrm{mg})$ was prepared in $\mathrm{CH}_{3} \mathrm{CN}(20 \mathrm{~mL})$. The stock solution $(20 \mu \mathrm{L})$ was diluted to $25 \mathrm{~mL}$ with $\mathrm{H}_{2} \mathrm{O}\left(\left[\mathbf{4 H}^{+}\right]=5.3 \times 10^{-6} \mathrm{M}\right)$ and this dilute solution was titrated with a diluted solution of $\mathrm{NaOH}$ until $\mathrm{pH} 9$ was reached. The $\mathrm{pH}$ of this latter solution was decreased to 3.0 with the addition of a diluted solution of $\mathrm{HCl}$. The $\mathrm{pH}$ was measured with a $\mathrm{pH}$-meter and UV-vis spectra were recorded. The measurements were performed at $25{ }^{\circ} \mathrm{C}$. The resulting UVvis spectra were processed by multivariate nonlinear regression analysis using the SPECFIT program. In the analysis a surface was fit that is defined by all UV-vis spectra from 242 to 486 $\mathrm{nm}$ at different $\mathrm{pH}$ values.

Alternatively, a stock solution of $4 \mathbf{H}^{+}(1.30 \mathrm{mg}$ or $3.42 \mathrm{mg})$ in $\mathrm{CH}_{3} \mathrm{CN}(10 \mathrm{~mL}$ or $25 \mathrm{~mL})$ was prepared and was diluted with $\mathrm{H}_{2} \mathrm{O}$ to achieve a $4 \mathbf{H}^{+}$concentration of $1.05 \times 10^{-5} \mathrm{M}$. A series of solutions was prepared by mixing the diluted $\mathbf{4} \mathbf{H}^{+}$solution in a $1: 1$ ratio with a solution of phosphate buffer of the appropriate $\mathrm{pH}$ (obtained by mixing $\mathrm{H}_{3} \mathrm{PO}_{4}, \mathrm{NaH}_{2} \mathrm{PO}_{4}$ and $\mathrm{Na}_{2} \mathrm{HPO}_{4}$ ). The total concentrations of compound and buffer after dilution was $5.3 \times 10^{-6} \mathrm{M}$, and $0.05 \mathrm{M}$, respectively.

For measurements in the presence of citrate buffer, a stock solution was prepared by dissolving $4 \mathbf{H}^{+}(3.25 \mathrm{mg}), \mathbf{3}(2.77 \mathrm{mg})$ or $\mathbf{2}(2.91 \mathrm{mg})$ in $\mathrm{CH}_{3} \mathrm{CN}(25 \mathrm{~mL})$, and the solutions were diluted 
with $\mathrm{H}_{2} \mathrm{O}$ to reach a concentration of $1.06 \times 10^{-4} \mathrm{M}$. A series of solutions was prepared by mixing the diluted $4 \mathbf{H}^{+}, \mathbf{3}$, or $\mathbf{2}$ solution in a 1:1 ratio with citrate buffer of the appropriate $\mathrm{pH}$. The total concentrations of compounds and buffer after dilution was $5.3 \times 10^{-5} \mathrm{M}$, and $0.05 \mathrm{M}$, respectively.

\section{Fluorescence titration}

The solutions of $\mathbf{2}, \mathbf{3}$ and $4 \mathbf{H}^{+}\left(5.3 \times 10^{-6} \mathrm{M}\right)$ in the presence of citrate buffer $(0.05 \mathrm{M})$ were prepared as described for the UV-vis studies. The $\mathrm{pH}$ was measured by a $\mathrm{pH}$-meter and fluorescence spectra at $25{ }^{\circ} \mathrm{C}$ were recorded on a spectrometer with slits set for a bandwidth of 10 or $20 \mathrm{~nm}$ for the excitation and emission monochromator. The resulting fluorescence spectra were processed by multivariate nonlinear regression analysis using the SPECFIT program. In the analysis, the surface was fit defined by all fluorescence spectra in the wavelength region from 410 to $680 \mathrm{~nm}$.

\section{Determination of the equilibrium constant between $4 \mathrm{H}^{+}$and $\mathrm{CB}[7]$}

A stock solution of $4 \mathbf{H}^{+}(545 \mu \mathrm{M})$ was prepared in $\mathrm{CH}_{3} \mathrm{CN}$. A solution of citrate buffer $(47 \mathrm{mM})$ was prepared by dissolving citric acid monohydrate $(0.7122 \mathrm{~g})$ and trisodium citrate dihydrate $(0.3807 \mathrm{~g})$ in $\mathrm{H}_{2} \mathrm{O}(100 \mathrm{~mL})$. The buffer had a $\mathrm{pH}$ of 3.5. A solution of $\mathrm{CB}$ [7] $(597 \mu \mathrm{M})$ in $\mathrm{H}_{2} \mathrm{O}$ was prepared, to which no $\mathrm{NaCl}$ was added. The citrate buffer was used to prepare the solution of $4 \mathbf{H}^{+}$and had a $\mathrm{Na}^{+}$cation concentration of $39 \mathrm{mM}$. In the titration experiment, $4 \mathbf{H}^{+}$was diluted with citrate buffer to reach a final concentration of $5 \mu \mathrm{M}$. The variations in the absorbance of $\mathbf{4} \mathbf{H}^{+}$with additions of $\mathrm{CB}[7]$ were measured with a $\mathrm{UV}$-vis spectrophotometer. Absorption spectra for blank solutions containing all chemicals except $\mathbf{4} \mathbf{H}^{+}$were subtracted from 
the spectra. Corrected absorbance values were used to determine the overall equilibrium binding constant for the complexation between $\mathbf{4} \mathbf{H}^{+}$and $\mathrm{CB}[7]$. The fitting of the binding isotherm was performed using the Scientist 3 software (see SI). A 1:1 binding model was used to fit the data. During the titration, $\mathbf{4} \mathbf{H}^{+}$solution was diluted by $5 \%$ and this dilution was taken into account during the fitting.

\section{Determination of the $\mathrm{p} K_{\mathrm{a}}$ for $4 \mathrm{H}^{+}$complexed with $\mathrm{CB}[7]$}

A stock solution of $4 \mathbf{H}^{+}(1.27 \mathrm{mg})$ in $\mathrm{CH}_{3} \mathrm{CN}(10 \mathrm{~mL})$ with a concentration of $4.95 \times 10^{-4} \mathrm{M}$ was prepared. A stock solution of $\mathrm{CB}[7]\left(1.0 \times 10^{-3} \mathrm{M}\right)$ was prepared by dissolving $\mathrm{CB}$ [7] (75.41 $\mathrm{mg}$, $79 \%$ purity determined by titration $)^{77}$ in aqueous solution of $\mathrm{NaCl}(50 \mathrm{~mL}$ of $0.1 \mathrm{M} \mathrm{NaCl})$. A series of solutions was prepared by adding $40 \mu \mathrm{L} \mathbf{4} \mathbf{H}^{+}$to $1.96 \mathrm{~mL}$ of the $\mathrm{CB}[7]$ solution and then mixing with $2.0 \mathrm{~mL}$ of phosphate buffer of the appropriate $\mathrm{pH}$ (obtained by mixing $\mathrm{NaH}_{2} \mathrm{PO}_{4}$ and $\mathrm{Na}_{2} \mathrm{HPO}_{4}$ ). The total concentration of $4 \mathbf{H}^{+}, \mathrm{CB}[7]$ and the buffer after dilution were $4.95 \times$ $10^{-6} \mathrm{M}, 5.02 \times 10^{-4} \mathrm{M}$, and $0.05 \mathrm{M}$, respectively. The $\mathrm{pH}$ was measured by a $\mathrm{pH}-\mathrm{meter}$ and the UV-vis spectra were recorded. The spectra were corrected by subtracting the spectrum of the solution containing $\mathrm{CB}[7](1.96 \mathrm{~mL}), \mathrm{CH}_{3} \mathrm{CN}(40 \mu \mathrm{L})$, and the phosphate buffer at $\mathrm{pH} 6.11(2$ $\mathrm{mL}$ ). The measurements were performed at $25{ }^{\circ} \mathrm{C}$. The resulting UV-vis spectra were processed by multivariate nonlinear regression analysis using the SPECFIT program. In the analysis the surface was fit defined by $18 \mathrm{UV}$-vis spectra in the wavelength region from 242 to $486 \mathrm{~nm}$.

\section{Laser Flash Photolysis (LFP)}

All LFP studies on a system previously described ${ }^{78}$ employed as an excitation source a QuantaRay Lab 130-4 pulsed Nd:YAG laser at $355 \mathrm{~nm}$ from Spectra Physics ( $<20 \mathrm{~mJ}$ per pulse), with a 
pulse width of $10 \mathrm{~ns}$. Static cells $(7 \mathrm{~mm} \times 7 \mathrm{~mm})$ were used and the solutions were purged with nitrogen or oxygen for $20 \mathrm{~min}$ prior to performing the measurements. Absorbances at $355 \mathrm{~nm}$ were $\sim 0.3-0.4$

For LFP experiments conducted at different $\mathrm{pH}$ values, the $\mathrm{pH}$ of the aqueous solution was measured by a $\mathrm{pH}$-meter, adjusted with $\mathrm{H}_{2} \mathrm{SO}_{4}, \mathrm{NaOH}$ or citrate buffer $(c=0.05 \mathrm{M})$, and then this aqueous solution was mixed with the $\mathrm{CH}_{3} \mathrm{CN}$ solution of 4 . The $\mathrm{pH}$ of the resulting $\mathrm{CH}_{3} \mathrm{CN}$ $\mathrm{H}_{2} \mathrm{O}(1: 1)$ solution was not measured.

\section{Acknowledgement}

These materials are based on work financed by the Croatian Foundation for Science (HRZZ), the Natural Sciences and Engineering Research Council (NSERC) of Canada and the University of Victoria.

Supporting information contains: computational results, UV-vis and fluorescence spectra, $\mathrm{pH}$ titration data for $\mathbf{2 - 4}$, titration data for $\mathbf{4}$ and $\mathbf{4} \mathbf{H}^{+}$with $\mathrm{CB}[7]$, LFP data and ${ }^{1} \mathrm{H}$ and ${ }^{13} \mathrm{C}$ NMR spectra of new compounds. This material is available free of charge via the Internet at http://pubs.acs.org.

\section{References:}

${ }^{1}$ Hydrogen-transfer reactions, Hynes, J.T.; Klinman, J.P.; Limbach, H.-H.; Schowen, R.L., Eds.; Wiley-VCH: Weinheim, 2007.

${ }^{2}$ Kwon, J.I.; Park, S.Y., Adv. Mater. 2011, 23, 3615-3642.

${ }^{3}$ Ireland, J.F.; Wyatt, P.A.H., Adv. Phys. Org. Chem. 1976, 12, 131-221. 
${ }^{4}$ Arnaut, L.G.; Formosinho, S.J., J. Photochem. Photobiol. A: Chem. 1993, 75, 1-20.

${ }^{5}$ Klöpffer, W., Adv. Photochem. 1977, 10, 311-358.

${ }^{6}$ Formosinho, S.J.; Arnaut, L.G., J. Photochem. Photobiol. A: Chem. 1993, 75, 21-48.

${ }^{7}$ Ormson, S.M.; Brown, R.G., Prog. React. Kinet. 1994, 19, 45-91.

${ }^{8}$ Le Gourrierec, D.; Ormson, S.M.; Brown, R.G., Prog. React. Kinet. 1994, 19, 211-275.

${ }^{9}$ Kasha, M., J. Chem. Soc. Faraday Trans. 2, 1986, 82, 2379-2392.

${ }^{10}$ Lill, M.A.; Helms, V., Proc. Nat. Acad. Sci. 2002, 99, 2778-2781.

${ }^{11}$ Faxén, K.; Gilderson, G.; Ädelroth, P.; Brzezinski, P., Nature 2005, 437, 286-289.

${ }^{12}$ Schäfer, L.V.; Groenhof, G.; Klingen, A.R.; Ullmann, G.L.; Boggio-Pasqua, M.; Robb, M.A.; Grubmüller, H., Angew. Chem. Int. Ed. 2007, 46, 530-536.

${ }^{13}$ Sobolewski, A. J.; Domcke, W., ChemPhysChem 2006, 7, 561-564.

${ }^{14}$ Meyer, T.J.; Huynh, M. H. V.; Thorp, H. H., Angew. Chem. Int. Ed. 2007, 46, 5284-5304.

${ }^{15}$ Hosler, J.P.; Ferguson-Miller, S.; Mills, D. A., Annu. Rev. Biochem. 2006, 75, 165-187.

${ }^{16}$ Royant, A.; Edman, K.; Ursby, T.; Pebay-Peyroula, E.; Landau, E.M.; Neutze, R., Nature 2000, 406, 645-648.

${ }^{17}$ Mathias, G.; Marx, D., Proc. Nat. Acad. Sci. 2007, 104, 6980-6985.

${ }^{18}$ Kwon, O.-H.; Lee, Y.-S.; Park, H.J.; Kim, Y.; Jang, D.-J., Angew. Chem. Int. Ed. 2004, 43, 5792-5796.

${ }^{19}$ Kohtani, S.; Tagami, A.; Nakagaki, R., Chem. Phys. Lett. 2000, 316, 88-93.

${ }^{20}$ Park, H.-J.; Kwon, O.-H.; Ah, C.S.; Jang, D.-J., J. Chem. Phys. B 2005, 109, 3938-3943.

${ }^{21}$ Kwon, O.-H.; Lee, Y.-S.; Yoo, B.K.; Jang, D.-J., Angew. Chem. Int. Ed. 2006, 45, 415-419.

${ }^{22}$ Park, S.-Y.; Lee, Y.-S.; Kwon, O.-H.; Jang, D.-J., Chem. Commun. 2009, 926-928.

${ }^{23}$ Park, S.-Y.; Jang, D.-J., J. Am. Chem. Soc. 2010, 132, 297-302.

${ }^{24}$ Smirnov, A.V.; English, D.S.; Rich, R.L.; Lane, J.; Teyton, L.; Schwabacher, A.W.; Luo, S.; Thornburg, R.W.; Petrich, J.W., J. Chem. Phys. B 1997, 101, 2758-2769. 
${ }^{25}$ Mukherjee, T. K.; Panda, D.; Datta, A., J. Phys. Chem. B 2005, 109, 18895-18901.

${ }^{26}$ Mukherjee, T. K.; Datta, A., J. Phys. Chem. B 2006, 110, 2611-2617.

${ }^{27}$ Kyrychenko, A.; Wu, F.; Thummel, R. P.; Waluk, J.; Ladokhin, A. S., J. Phys. Chem. B 2010, 114, 13574-13578.

${ }^{28}$ Kyrychenko, A.; Herbich, J.; Waluk, J. in Tautomerism Methods and Theories. Antonov L. (Ed.) Wiley-VCH, Weinheim: 2014. pp 49.

${ }^{29}$ Herbich, J.; Rettig, W.; Waluk, J., Chem. Phys. Lett. 1992, 195, 556-562.

${ }^{30}$ Herbich, J.; Hung, C.-Y.; Thummel, R.P.; Waluk, J., J. Am. Chem. Soc. 1996, 118, 3508-3518.

${ }^{31}$ Kijak, M.; Zielińska, A.; Chamchoumis, C.; Herbich, J.; Thummel, R.P.; Waluk, J., Chem. Phys. Lett. 2004, 400, 279-285.

32 Petkova, I.; Mudadu, M.S.; Singh, A.; Thummel, R.P.; van Stokkum, I.H.M.; Buma, W.J.; Waluk, J., J. Phys. Chem. A 2007, 111, 11400-11409.

${ }^{33}$ Nosenko, Y.; Wiosna-Sałyga, G.; Kunitski, M.; Petkova, I.; Singh, A.; Buma, W.J.; Thummel, R.P.; Brutschy, B.; Waluk, J., Angew. Chem. Int. Ed. 2008, 47, 6037-6040.

${ }^{34}$ Kyrychenko, A.; Herbich, J.; Thummel, R.P.; Waluk, J., J. Am. Chem. Soc. 2000, 122, 28182827.

35 Wiosna, G.; Petkova, I.; Mudadu, M.S.; Thummel, R.P.; Waluk, J., Chem. Phys. Lett. 2004, 400, 379-383.

${ }^{36}$ Vetohkina, V.; Kijak, M.; Wiosna-Sałyga, G.; Thummel, R.P.; Herbich, J.; Waluk, Photochem. Photobiol. Sci., 2010, 9, 923-930.

${ }^{37}$ Assaf, K. I.; Nau, W. M., Chem. Soc. Rev. 2015, 44, 394-418.

${ }^{38}$ Pavari, G.; Reany, O.; Keinan, O., Isr. J. Chem. 2011, 51, 646-663.

${ }^{39}$ Macartney, D.H.; Isr. J. Chem. 2011, 51, 600-615.

${ }^{40}$ Walker, S.; Oun, R.; McInnes, F.J.; Wheate, N.J., Isr. J. Chem. 2011, 51, 616-624.

${ }^{41}$ Day, A.I.; Collins, J.G., In: Supramolecular Chemistry: From Molecules to Nanomaterials, Steed, J. W.; Gale, P. A. Eds, John Wiley \& Sons, 2012.

${ }^{42}$ Lagona, J.; Mukhopadhyay, P.; Chakrabarti, S.; Isaacs, L., Angew. Chem. Int. Ed. 2005, 44, 4844-4870. 
${ }^{43}$ Masson, E.; Ling, X.; Joseph, R.; Kyeremeh-Mensah, L.; Lu, X., RSC Advances 2012, 2 , 1213-1247.

${ }^{44}$ Butterworth, E. C.; Heilbron, I. M.; Hey, D. H. J. Chem. Soc. 1940, 355-358.

${ }^{45}$ Hey, D. H.; Stirling, C. J. M.; Gareth H. W., J. Chem. Soc. 1955, 3963-3969.

${ }^{46}$ Martina, S.; Enkelmann, V.; Wegner, G.; Schlüter, A.-D., Synthesis 1991, 613-615.

${ }^{47}$ Alešković, M.; Basarić, N.; Mlinarić-Majerski, K., J. Heterocycl. Chem. 2011, 48, 1329-1335.

${ }^{48}$ Lucchesini, F. Tetrahedron 1992, 48, 9951-9966.

${ }^{49}$ Choi-Sledeski, Y. M.; McGarry, D. G.; Green, D. M.; Mason, H.J.; Becker, M. R.; Davis, R. S.; Ewing, W. R.; Dankulich, W. P.; Manetta, V. E.; Morris, R. L.; Spada, A. P.; Cheney, D. L.; Brown, K. D.; Colussi, D. J.; Chu, V.; Heran, C. L.; Morgan, S. R.; Bentley, R. G.; Leadley, R. J.; Maignan, S.; Guilloteau, J.-P.; Dunwiddie, C. T.; Pauls, H. W., J. Med. Chem. 1999, 42, 3572-3587.

${ }^{50}$ Wakabayashi, S.; Sugihara, Y.; Takakura, K.; Murata, S.; Tomioka, H.; Ohnishi, S.; Tatsumi, K. J. Org. Chem. 1999, 64, 6999-7008.

51 Toscano, R. A.; Hernández-Galindo, M. C.; García-Mellado, R. R. O.; Portilla, F. R.; Amábile-Cuevas, C.; Álvarez-Tolenado, C., Chem. Pharm. Bull. 1997, 45, 957-961.

${ }^{52}$ Montalti, M.; Credi, A.; Prodi, L.; Gandolfi, M.T., In Handbook of Photochemistry; CRC Taylor and Francis: Boca Raton, 2006.

${ }^{53}$ Olmsted, J., J. Phys. Chem. 1979, 83, 2581-2584.

${ }^{54}$ Grampp, H.; Maeder, M.; Meyer, C.J.; Zuberbühler, A.D. Talanta 1985, 32, 95-101.

${ }^{55}$ Grampp, H.; Maeder, M.; Meyer, C.J.; Zuberbühler, A.D. Talanta 1985, 32, 257-264.

${ }^{56}$ Grampp, H.; Maeder, M.; Meyer, C.J.; Zuberbühler, A.D. Talanta 1985, 32, 1133-1139.

${ }^{57}$ Joule, J.A.; Mills, K., Heterocyclic Chemistry, Blackwell Publishing, Oxford: 2000.

${ }^{58}$ Tang, H.; Fuentealba, D.; Ho Ko, Y.; Selvapalam, N.; Kim, K.; Bohne, C., J. Am. Chem. Soc. 2011, 133, 20623-20633.

${ }^{59}$ Mohanty, J.; Bhasikuttan, A.C.; Nau, W.M.; Pal, H., J. Phys. Chem. B 2006, 110, 5132-5138.;

${ }^{60}$ Koner, A.L.; Ghosh, I.; Saleh, N.; Nau, W.M., Can. J. Chem. 2011, 89, 139-147. 
${ }^{61}$ Shaikh, M.; Dutta Choudhury, S.; Mothany, J.; Bhasikuttan, A.C.; Nau, W.M.; Pal, H., Chem. Eur. J. 2009, 15, 12362-12370.

62 Pischel, U.; Uzunova, V.D.; Remón, P.; Nau, W.M., Chem. Commun. 2010, 46, 2635-2637.

${ }^{63}$ Shaikh, M.; Mohanty, J.; Bhasikuttan, A.C.; Uzunova, V.D.; Nau, W.M.; Pal, H., Chem. Commun. 2008, 44, 3681-3683.

${ }^{64}$ Saleh, N.; Koner, A.L.; Nau, W.M., Angew. Chem. Int. Ed. 2008, 47, 5398-5401.

${ }^{65}$ Parente Carvalho, C.; Uzunova, V.D.; Da Silva, J.P.; Nau, W.M.; Pischel, U., Chem. Commun. 2011, 47, 8793-8795.

${ }^{66}$ Basarić, N.; Franco-Cea, A.; Alešković, M.; Mlinarić-Majerski, K.; Wan, P., Photochem. Photobiol. Sci. 2010, 9, 779-790.

${ }^{67}$ Bent, D.V.; Hayon, E., J. Am. Chem. Soc., 1975, 97, 2612-2619.

${ }^{68}$ Moorthy, P.N.; Hayon, E.; J. Phys. Chem., 1974, 78, 2615-2620.

${ }^{69}$ Fang, X.; Jin, F.; Jin, H.; von Sonntag, C., J. Chem. Soc. Perkin 2 1998, 259-263.

70 Basarić, N.; Wan, P., Photochem. Photobiol. Sci. 2006, 5, 656-664.

${ }^{71}$ Hansen, P.E. in Tautomerism Methods and Theories. Antonov L. (Ed.) Wiley-VCH, Weinheim: 2014. pp143.

72 Basarić, N.; Cindro, N.; Bobinac, D.; Uzelac, L.; Mlinarić-Majerski, K.; Kralj, M.; Wan, P., Photochem. Photobiol. Sci. 2012, 11, 381-396.

${ }^{73}$ Chiang, Y.; Kresge, A.J.; Zhu, Y., J. Am. Chem. Soc. 2000, 122, 9854-9855.

74 Wirz, J., Pure Appl. Chem. 1998, 70, 2221-2232.

75 A. P. Pelliccioli, P. Šebej, J. Wirz, Photochem. Photobiol. Sci. 2012, 11, 967-971.

${ }^{76}$ Gaussian 03, Rev E. 01, Frisch, M. J.; Trucks, G. W.; Schlegel, H. B.; Scuseria, G. E.; Robb, M. A.; Cheeseman, J. R.; Montgomery, Jr., J. A.; Vreven, T.; Kudin, K. N.; Burant, J. C.; Millam, J. M.; Iyengar, S. S.; Tomasi, J.; Barone, V.; Mennucci, B.; Cossi, M.; Scalmani, G.; Rega, N.; Petersson, G. A.; Nakatsuji, H.; Hada, M.; Ehara, M.; Toyota, K.; Fukuda, R.; Hasegawa, J.; Ishida, M.; Nakajima, T.; Honda, Y.; Kitao, O.; Nakai, H.; Klene, M.; Li, X.; Knox, J. E.; Hratchian, H. P.; Cross, J. B.; Adamo, C.; Jaramillo, J.; Gomperts, R.; Stratmann, R. E.; Yazyev, O.; Austin, A. J.; Cammi, R.; Pomelli, C.; Ochterski, J. W.; Ayala, P. Y.; Morokuma, K.; Voth, G. A.; Salvador, P.; Dannenberg, J. J.; Zakrzewski, V. G.; Dapprich, S.; 
Daniels, A. D.; Strain, M. C.; Farkas, O.; Malick, D. K.; Rabuck, A. D.; Raghavachari, K.;

Foresman, J. B.; Ortiz, J. V.; Cui, Q.; Baboul, A. G.; Clifford, S.; Cioslowski, J.; Stefanov, B. B.; Liu, G.; Liashenko, A.; Piskorz, P.; Komaromi, I.; Martin, R. L.; Fox, D. J.; Keith, T.; AlLaham, M. A.; Peng, C. Y.; Nanayakkara, A.; Challacombe, M.; Gill, P. M. W.; Johnson, B.; Chen, W.; Wong, M. W.; Gonzalez, C.; and Pople, J. A.; Gaussian, Inc., Pittsburgh PA, 2003.

77 Yi, S.; Kaifer, A. E., J. Org. Chem. 2011, 76, 10275-10278.

${ }^{78}$ Liao, Y.; Bohne, C. J. Phys. Chem., 1996, 100, 734-743. 